\title{
Scholars' Briefs and the Vocation of the Law Professor
}

\section{Citation}

Richard H. Fallon Jr., Scholars' Briefs and the Vocation of the Law Professor (2011).

\section{Permanent link}

http://nrs.harvard.edu/urn-3:HUL.InstRepos:5371988

\section{Terms of Use}

This article was downloaded from Harvard University's DASH repository, and is made available under the terms and conditions applicable to Open Access Policy Articles, as set forth at http:// nrs.harvard.edu/urn-3:HUL.InstRepos:dash.current.terms-of-use\#OAP

\section{Share Your Story}

The Harvard community has made this article openly available. Please share how this access benefits you. Submit a story.

Accessibility 


\section{Scholars' Briefs and the Vocation of a Law Professor By Richard H. Fallon, Jr. ${ }^{1}$}

At least within the loosely defined domain of public law, any law professor who does not get asked to sign "scholars' briefs" is not much of a scholar. Scholars' briefs, in which collections of professors appear as amici curiae to support a party in litigation before a court, appear to grow more common each year. During the 2010 Term, in which the Supreme Court decided 85 cases, it received 56 briefs on behalf of groups of selfidentified legal scholars or law professors, with at least one such brief being filed in 30 cases, or more than a third of the total. ${ }^{2}$ In at least seven cases, dueling teams of scholars filed briefs supporting opposing sides. ${ }^{3}$ By contrast, during the Court's 1985 Term, the Justices decided 159 cases ${ }^{4}$ yet received only three scholars' briefs. ${ }^{5}$

\footnotetext{
${ }^{1}$ Ralph S. Tyler, Jr. Professor of Constitutional Law, Harvard Law School. I am grateful to Betsy Bartholet, John Coates, Jesse Choper, Glen Cohen, Ronald Dworkin, Charles Fried, Barry Friedman, John Goldberg, Philip Hamburger, Debbie Hellman, Ben Heineman, Steve Horowitz, Vicki Jackson, Richard Lazarus, Daryl Levinson, Dan Meltzer, Thomas Nagel, Athnea Roberts, Ben Roin, David Shapiro, Stephen Shay, David Strauss, Detlev Vagts, David Wilkins, and participants in a Harvard Law School Faculty Workshop and the NYU Colloquium for Legal, Political and Social Philosophy for extremely insightful comments on earlier drafts, to Alan Dershowitz and Andy Kaufman, for helpful conversation, and to Alexander Dryer, Patrick Gibson, and Stephanie Young for research assistance.

${ }^{2}$ The Court decided 85 cases overall, but seven of the decisions were per curiam in cases without briefing on the merits. To identify the number of scholars' briefs filed, my research assistants did a Lexis search of amicus briefs submitted in the 2010 Term that contained the words "scholar" or "professor" in their titles. They then, separately, looked at all other amicus briefs for argued cases to determine whether the amici identified themselves as professors. Out of the 63 briefs that they identified this way, I excluded six on the ground that the amici were either professors emeriti, professors in fields other than law, law professors from outside of the United States, or were associated with U.S. law schools in some capacity but lacked professorial appointments.

${ }^{3}$ In three cases, there were multiple professors' briefs on at least one side. See Am. Elec. Power Co., Inc. v. Connecticut, 131 S.Ct. 2527 (2011), in which there were three briefs each for petitioner (Brief of Law Professors as Amici Curiae in Support of Petitioners, Am. Elec. Power Inc., 131 S.Ct. 2527 (No. 10-174), 2011 U.S. S. Ct. Briefs LEXIS 189; Brief of Amicus Curiae Nicholas Johnson in Support of Petitioners, Am. Elec. Power Inc., 131 S.Ct. 2527 (No. 10-174), 2011 U.S. S. Ct. Briefs LEXIS 184; Brief of Law Professors as Amici Curiae in Support of Petitioners, Am. Elec. Power Inc., 131 S.Ct. 2527 (No. 10-174), 2010 U.S. S. Ct. Briefs LEXIS 2268 (urging that the Court grant certiorari)) and for respondent (Brief Amici Curiae of Tort Law Scholars in Support of Respondents, Am. Elec. Power Inc., 131 S.Ct. 2527 (No. 10-174), 2011 U.S. S. Ct. Briefs LEXIS 368 Brief of Environmental Law Professors as Amici Curiae in Support of Respondents, Am. Elec. Power Inc., 131 S.Ct. 2527 (No. 10-174), 2011 U.S. S. Ct. Briefs LEXIS _ 372; Brief of Law Professors as Amici Curiae in Support of Respondents, Am. Elec. Power Inc., 131 S.Ct. 2527 (No. 10-174), 2011 U.S. S. Ct. Briefs LEXIS 360); AT\&T v. Concepcion, 131 S. Ct. 1740 (2011), in which there were four briefs in support of respondent (Brief of Civil Procedure and Complex Litigation Professors as Amici Curiae in Support of Respondents, AT\&T, 131 S.Ct. 1740 (No. 09-893), 2010 U.S. S. Ct. Briefs LEXIS 1940; Brief of Federal Jurisdiction Professors as Amici Curiae in Support of Respondents, AT\&T, 131 S.Ct. 1740 (No. 09-893), 2010 U.S. S. Ct. Briefs LEXIS 1932; Brief of Contracts Professors as Amici Curiae in Support of Respondents, AT\&T, 131 S.Ct. 1740 (No. 09-893), 2010 U.S. S. Ct. Briefs LEXIS 1934; Brief of Arbitration Professors as Amici Curiae in Support of Respondents, AT\&T, 131 S.Ct. 1740 (No. 09-893), 2010 U.S. S. Ct. Briefs LEXIS 1936) and one in support of petitioner (Brief Amici Curiae of Distinguished Law Professors in Support of Petitioner, \&T, 131 S.Ct. 1740 (No. 09-893), 2010 U.S. S. Ct. Briefs LEXIS 1042); and Global-Tech Appliances, Inc. v. SEB S.A., 131 S. Ct. 2060 (2011), in which there were two briefs for petitioner (Brief Amici Curiae of 41 Law, Economics, and
} 
Litigants and their lawyers obviously believe that "scholars' briefs"-a term I use to refer both to those that are explicitly so designated and to other law professors' briefs whose signatories represent that their only interest lies in the proper development of the law-provide important support for their causes. ${ }^{6}$ Surveys of judges, Justices, and law clerks point to the same conclusion. In a questionnaire sent to judges and Justices about amicus curiae briefs in general, one researcher included a query specifically about law professors' briefs, the responses to which she summarized as follows:

As experts in particular fields of law, professors are able to offer an informed legal analysis of a pressing legal question from a relatively

Business Professors in Support of Petitioner, Global-Tech Appliances, Inc., 131 S. Ct. 2060 (No. 10-06) 2010 U.S. S. Ct. Briefs LEXIS 2329; Brief Amici Curiae of 26 Law, Economics, and Business Professors in Support of Petitioner, Global-Tech Appliances, Inc., 131 S. Ct. 2060 (No. 10-06) 2010 U.S. S. Ct. Briefs LEXIS 2054) and one for respondent (Brief of Law Professors, as Amicus Curiae, in Support of Respondent, Global-Tech Appliances, Inc., 131 S. Ct. 2060 (No. 10-06), 2010 U.S. S. Ct. Briefs LEXIS 5). In four additional cases, there was one professors' brief on each side. See Erica P. John Fund, Inc. v. Halliburton Co., 131 S. Ct. 2179 (2011) (Brief for Law Professors Robert Bartlett, et al, as Amici Curiae in Support of Petitioners, Erica P. John Fund, Inc. 131 S. Ct. 2179 (No. 09-1403), 2010 U.S. S. Ct. Briefs LEXIS 306; and, Brief of Law Professors as Amici Curiae in Support of Respondents, Erica P. John Fund, Inc. 131 S. Ct. 2179 (No. 09-1403), 2010 U.S. S. Ct. Briefs LEXIS 424); Mayo Found. v. U.S., 131 S. Ct. 704 (2011) (Brief of Amicus Curiae Professor Kristin E. Hickman in Support of Respondent, Mayo $131 \mathrm{~S}$. Ct. 704 (No. 09-837), 2010 U.S. S. Ct. Briefs LEXIS 1925; and, Brief of Tax Professor Carlton M. Smith as Amicus Curiae in Support of the Petitioners, Mayo 131 S. Ct. 704 (No. 09-837), 2010 U.S. S. Ct. Briefs LEXIS 1260); Sorrell v. IMS Health Inc., 131 S.Ct. 2653 (2011) (Brief for Dr. Khaled el Emam and Jane Yakowitz, Esq. as Amici Curiae for Respondents, Sorrell 131 S.Ct. 2653 (No. 10-779), 2011 U.S. S. Ct. Briefs LEXIS 433; and, Brief of Amici Curiae Electronic Privacy Information Center (EPIC) and Legal Scholars and Technical Experts in Support of the Petitioners, 131 S.Ct. 2653 (No. 10-779), 2011 U.S. S. Ct. Briefs LEXIS 267); and Stern v. Marshall, 131 S. Ct. 2592 (2011) (Brief of Amici Curiae Law Professors S. Todd Brown, G. Marcus Cole, Ronald D. Rotunda, and Todd J. Zywicki in Support of Respondent, Stern 131 S. Ct. 2592 (No. 10-189) 2010 U.S. S. Ct. Briefs LEXIS 2346; and, Brief in Support of Petitioner for Amici Curiae Professors Richard Aaron, et al, Stern 131 S. Ct. 2592 (No. 10-189) 2010 U.S. S. Ct. Briefs LEXIS 2094).

${ }^{4}$ See The Supreme Court, 1985 Term: Leading Cases, The Statistics, 100 Harv. L. Rev. 304 (1986).

${ }^{5}$ One of the briefs came in Thornburg v. American College of Obstetricians and Gynecologists, 476 U.S. 747 (1986), one was submitted in Diamond v. Charles, 476 U.S. 54 (1986), and the other in Bowers v. Hardwick, 478 U.S. 186 (1986). Although the brief in Bowers was filed by Professor David Robinson of the George Washington University Law School, it focused much more on public health issues than on legal issues and fits only maginally within the category of legal scholars' briefs with which I am concerned. The briefs cited in this footnote were again located by a research assistant, who employed the same research methodology described in note _, supra.

The increase in the number of scholars' briefs may be part of a general phenomenon of increasing numbers of amicus curiae — or "friend of the court" — briefs filed by non-parties more generally. See Richard J. Lazarus, Advocacy Matters Before and Within the Supreme Court: Transforming the Court by Transforming the Bar, 96 GEO. L.J. 1487, 1514 (2008) ("There was an average of just under three amicus briefs filed for every case heard on the merits from 1976 through 1985, compared to an average of about nine amicus briefs filed for every case head on the merits in October term 2005-a more than 300\% relatie increase.”); Linda Sandstrom Simard, An Empirical Study of Amici Curiae in Federal Court: A Fine Balance of Access, Efficiency, and Adversarialism, 27 REV. LITIG. 669, 671-72 (2008) (noting that during the second half of the twentieth century "the Supreme Court saw an $800 \%$ increase in the number of amicus filings).

${ }^{6}$ See infra notes _____ (discussing the grounds for this belief). 
neutral perspective. Thus, it is not surprising that all of the [three]

Supreme Court [Justices who responded] indicated that law professors are moderately helpful to the [adjudicatory] process, as did $56.6 \%$ of Circuit Court respondents and $52.8 \%$ of District Court respondents. ${ }^{7}$

Another survey of Supreme Court law clerks found that "[t]he overwhelming majority of clerks (88\%) indicated that they would be inclined to give an amicus brief filed by an academic closer attention [than most other amicus briefs]—at least initially."8

With scholars' briefs having the potential to influence the outcome of sometimes high-stakes litigation, requests to prepare them often come either from a party or from a firm or organization whose interests align with those of a party. ${ }^{9}$ Many law professors seem to like to draft, or at least collaborate with law firms in drafting, scholars' briefs. ${ }^{10}$

For the professors who are asked merely to sign a scholars' brief, participation may be even harder to resist. Dangled before them, with little or no work required, is the possibility of having an impact on the development of the law. As long as the brief supports the right side, it is hard for a professor who wants to influence the law's trajectory-as nearly all of us do-to say no.

But law professors often should say no, or at least we should say no much more frequently than many of us now do. And when we say yes-as we should sometimes-we should insist that scholars' briefs reflect higher norms of scholarly integrity than many such briefs now satisfy. Or so I shall argue in this essay.

In so arguing, I hope to spur an overdue discussion. The subject of scholars' briefs, and the standards that law professors ought to apply in determining whether to sign them, has received almost no attention in the literature. ${ }^{11}$ Yet the topic is an important one. Besides forming an increasingly

\footnotetext{
${ }^{7}$ Simard, supra note _, at 698-99.

${ }^{8}$ Kelly J. Lynch, Best Friends? Supreme Court Law Clerks on Effective Amicus Curiae Briefs, 20 J.L. \& PoL. 33, 52 (2004). A possible explanation is that clerks who are overwhelmed with more briefs than they can read carefully at least begin by paying special attention to those briefs carrying names that they recognize and associate with expertise. Cf. Lazarus, supra note _, at 1526, 1542 (maintaining that experienced Supreme Court advocates have enhanced credibility with law clerks).

${ }^{9}$ Although not speaking specifically of scholars' briefs, Simard, supra note _, at 708-09, notes that "litigants are quite strategic about the process of soliciting and managing amici participation." Supreme Court Rule 37.6 now provides that amicus briefs must indicate whether counsel for a party authored the brief in whole or in part and must identify any person other than the amicus, its members, or its counsel who made a financial contribution to the brief's preparation.

${ }^{10}$ A friend tells a revealing anecdote about being solicited by a lawyer from a law firm to take the lead in organizing a scholars' brief. Why, the friend asked, would the lawyer, who was being paid by a client, expect a law professor to work on an amicus brief for free? The reported response: "There are lots of law profs eager to file a brief in the Supreme Court so we don't need to pay.” Email from Barry Friedman, Professor of Law, New York University School of Law, to Richard Fallon, Professor of Law, Harvard Law School (July 13, 2011) (on file with author).

${ }^{11}$ During the controversy surrounding the impeachment of President Bill Clinton, hundreds of law professors signed a joint letter opining that the conduct in which Clinton was alleged to have engaged did
} 
significant component of many law professors' professional lives, scholars' briefs open a window onto broader questions about law professors' professional roles. We are long past the day, if there ever was one, when most law professors thought their sole professional contributions should come through traditional scholarship and teaching. Modern law professors familiarly participate in law reform initiatives, take on paid and unpaid client representation, and write regularly for non-scholarly audiences. Indeed, many law schools now boast in their alumni magazines and on their websites whenever their faculty publish op-ed articles, appear on radio or television programs, or even post comments on blogs.

In my view, participation in scholars' briefs gives rise to more complex ethical issues than do most of the other sub-roles that law professors play, largely because the signers of scholars' briefs represent their submissions as offering distinctively scholarly expertise and perspective. But there is of course no complete divorce between the role of teacher and scholar, on the one hand, and most of the other law-related functions that law professors sometimes take on. To be blunt, law professors recurrently attempt to leverage their credibility as teachers and scholars to influence non-scholarly audiences, sometimes for personal gain and sometimes without satisfying the standards on which their scholarly reputations depend. When law professors seek to trade on their academic reputations in the performance of non-academic roles, two sets of moral and ethical issues arise. One involves the extent, if any, to which an implied warranty of scholarly integrity ought to preclude professors from making assertions to courts or to non-scholarly audiences that they would not make in scholarly books or articles. The other set of worries involves the risk that nonscholarly activities — which would otherwise be permissible or even admirable in themselves - might inhibit future scholarly assertion of inconvenient truths.

Although my central focus is on scholars' briefs, it is impossible to think deeply about the standards that law professors ought to apply to requests to sign them without also reflecting on the standards that law professors ought to apply in other roles. As a result, my discussion in this Essay will range rather broadly at some points. Part I provides an admittedly impressionistic survey of current practice regarding scholars' briefs. Part II then begins an examination of the moral and ethical issues that requests to participate in such briefs raise by contrasting the role of amici professors with that of other parties to litigation. It also contrasts the norms of scholarly integrity that apply to professors publishing

not constitute "high Crimes and Misdemeanors" in the constitutional sense. See Neal Devins, Bearing False Witness: The Clinton Impeachment and the Future of Academic Freedom, 148 U. PA. L. REV. 165 (1999). Shortly thereafter, a pair of articles debated the propriety of law professors with widely varied levels of specifically pertinent expertise signing group letters expressing legal judgments. See Devins, supra note _; Cass R. Sunstein, Professors and Politics, 148 U. PA. L. REV. 191 (1999). In a follow-on published more than a decade ago, Ward Farnsworth thoughtfully expanded the discussion to include scholars' briefs. See Ward Farnsworth, Talking Out of School: Notes on the Transmission of Intellectual Capital From the Legal Academy to Public Tribunals, 81 B.U. L. ReV. 13 (2001). Since then, however, the topic of professorial integrity in regard to scholars' briefs has lain almost entirely dormant. 
books and articles with those applicable to lawyers filing briefs on behalf of clients.

With the argument in Part II having assumed that morality is partly rolebased, Part III develops a framework for considering how moral and ethical obligations - which it distinguishes - can vary from one role (such as that of lawyer for a client) to another (such as that of author of scholarly publications). To give context to judgments about the norms appropriate to participation in scholars' briefs, Part III also briefly surveys the moral and ethical obligations that attach to some of the other sub-roles that law professors sometimes inhabit.

Part IV proposes standards of scholarly integrity that law professors should apply in determining whether to sign scholars' briefs. It maintains that norms of scholarly integrity should bar law professors from signing scholars' briefs unless they have personal knowledge of all of the principal authorities on which a brief relies. More substantively, it argues that professors should not sign a brief unless, in their roles as scholars and teachers, they would applaud a court that simply adopted the brief's reasoning as its own or they make clear that they have assumed arguendo the validity of premises that they would otherwise contest. Part IV also draws similar conclusions about other collective expressions of purportedly expert legal opinions.

Part $\mathrm{V}$ considers and rejects possible objections to the stringent requirements that Part IV proposes. Part VI is a brief conclusion.

\section{Emerging Practice and Some Tentative Grounds for Uneasiness}

No writing of which I am aware provides more than a cursory description of current practices surrounding scholars' briefs. To ground the mostly normative discussion that will follow, let me begin by describing the kind of situation-which I believe to be quite common-that provokes my concern.

I am a law professor with expertise (or so I would say) in the fields of Constitutional Law and Federal Courts. I also have political or ideological views. Beyond doubt, those views sometimes color my judgment about how the law ought to develop. When I know only scanty details about the issues that a case presents, my political values are likely to have a particularly strong effect on my initial, tentative judgment about how the case should come out. With reasonable frequency, however, closer study will alter my views, which I hope display what Professor Dworkin calls "integrity." ${ }^{12}$ For me-as I believe for most law professors-what counts as the best or correct resolution of a legal issue depends partly on how the result would cohere or fail to cohere with a sometimes intricate network of existing authorities. Giving proper account to such considerations of "fit" often takes careful study and deliberation, ${ }^{13}$ even for someone with general expertise in a field. I thus assume that-for others as well as

${ }^{12}$ See RONALD DWORKIN, LAW's EMPIRE 164-67, 225-75 (1986).

${ }^{13}$ See id. at 239, 255-58 (discussing “fit” as an integral element of legal interpretation). 
myself-a sincere, informed judgment about how a legal issue ought to be resolved is not a mere expression of political preference.

Nevertheless, at least within the fields of Constitutional Law and Federal Courts, solicitation of participation in scholars' briefs almost invariably occurs with ideological views in mind. A friend, acquaintance, or occasionally a stranger will ask me to consider either taking the lead in developing a scholars' brief or joining a brief that champions a position with which the solicitor expects me to sympathize. Ideally, however, those seeking participants would like the list to signal that scholars of all political stripes have arrived at a particular conclusion based on their disinterested legal expertise. ${ }^{14}$ When I am solicited, typically based on the assumption that my generally liberal leanings make me a good candidate to support the conclusion that a brief urges, the solicitor frequently inquires whether I know of any conservative professors who also might agree. Colleagues tell similar stories. Nothing is more welcome than participation of perceived conservatives in briefs taking liberal positions and of perceived liberals in conservative briefs.

Nearly as often as not, the scholars' briefs that I am asked to sign have been researched and written not by a scholar, but by lawyers in a law firm. When lawyers write the briefs, one or more professors may play guiding roles, almost always on the basis of deep general knowledge, and sometimes abetted by further, case-specific research. After a brief is completed, the authors will do their best to accommodate suggestions by any solicited signatory as long as the suggestions accord with their draft's general approach. Typically, however, solicitation comes close to the deadline for a brief's submission. Only rarely does an effort to get a large number of scholars to contribute their expertise, or pool their individual insights, occur at the front-end of the process.

In every case in which I have been solicited to sign a scholars' brief, the brief was by all appearances very competent. If I may flatter my fellow professors, the briefs that they write tend to be better, on average, than those that practicing lawyers draft for law professors to sign. Among other things, amicus briefs written by law professors are more likely to contain distinctive insights not already included in the parties' briefsthough they by no means always do so, as I shall explain more fully below. But in saying that the scholars' briefs that I have been asked to join generally seem to me to be very competent, I must emphasize two qualifications.

First, although the briefs that are sent to me invariably address issues within my general expertise, my knowledge rarely extends to everything that the briefs assert. An example may clarify the distinction. As the Supreme Court began its 2010 Term, a friend asked me to consider signing an amicus brief on behalf of "law professors who teach and

\footnotetext{
${ }^{14}$ In an empirical study of Supreme Court law clerks, “[m]any clerks said”- -albeit not with specific regard to legal scholars- "that they would read a brief filed by unexpected allies simply because they would be [unusually] interested to see what it said.” Lynch, supra note _, at 64.
} 
write in the area of constitutional law, federal courts, and federal jurisdiction.” ${ }^{15}$ The brief addressed a highly complex question of federal jurisdiction over a habeas corpus petition filed by a prison inmate who had been convicted by a California state court and who, the California Supreme Court ruled, had failed to bring a timely appeal within the state judicial system. The brief asserted that the prison warden who was the "respondent" in the action had asked the Justices to raise even further the already imposing barrier to federal judicial review in cases in which state courts refuse to address constitutional claims. ${ }^{16}$ The sole ground for my hesitation in pronouncing the brief-which was written by Professor Michael Dorf-to be simply exemplary in all respects is that it relied on so many cases. Of the dozens of Supreme Court decisions to which the brief referred, there were some that I know well, but others that I recall only hazily at best. The brief also cited at least nine Supreme Court cases that I cannot remember ever having read at all, and twelve lower court decisions that I know I have never read. With respect to the brief's treatment of these authorities, how could I say more than that my highly favorable appraisal rested on “appearances”?

The second qualification involves my attachment of the word "competent" to the word "brief." When making claims that I know enough to assess, the scholars' briefs that I am asked to sign often advance assertions that lie within the fair bounds of legal argument, but that nonetheless seem to me to be oversimplified. Assertions that "Case $\mathrm{X}$ stands for Proposition Y” often occupy this category. But I can perhaps more clearly illustrate the point with another example.

Within the year, a justly renowned law professor asked me to join a scholars' brief (to be filed in a lower federal court) supporting the constitutionality of the provision of the recently enacted national health care law that requires some individuals either to purchase health insurance or pay a penalty. ${ }^{17}$ Apparently in order to address challengers' claims that the mandate exceeds Congress's originally understood powers under the Commerce Clause, the brief emphasized a historical argument in favor of constitutionality. ${ }^{18}$

\footnotetext{
${ }^{15}$ The brief was filed in Walker v. Martin, 131 S. Ct. 1120 (2011). See Amici Curiae Brief of Federal Courts Scholars in Support of Respondent, Walker 131 S. Ct. 1120 (No. 09-996), 2010 U.S. Sup. Ct. Briefs LEXIS 1992.

${ }^{16}$ See id. at $* * 8-9$.

${ }^{17}$ The brief has now been revised, and slightly different versions have been filed in different courts. The most recent version is Brief of Law Professors Barry Friedman, Matthew Adler, et al., in Support of Defendants-Appellees, Seven-Sky v. Holder, 2011 WL 1113489 (No. 11-5047) (D.C. Cir. 2011).

${ }^{18}$ The place of the original understanding in constitutional adjudication is complex and contested. Positions range from the view that originalism is necessary and inescapable for there to be genuine constitutional "interpretation," see, e.g., KeITH E. WhITTINGTON, CONSTITUTIONAL INTERPRETATION: TeXtual MEAning, ORIGinal InTENT, AND Judicial REviEW 60-61, 88-89 (1999), to the view that any robust form of originalism is unworkable or nonsensical, see, e.g., Mitchell N. Berman, Originalism Is Bunk, 84 N.Y.U. L. REV. 1 (2009). Nevertheless, nearly everybody believes the original history and understanding of constitutional provisions to be at least relevant to constitutional adjudication, insofar as it can be ascertained. The sharpest disagreements involve the proper answers to at least two, closely related questions. See Richard H. Fallon, Jr., Are Originalist Constitutional Theories Principled, or Are They Rationalizations for Conservatism?, 34 HARV. J. L. \& PUB. POL’y 5, 8-11 (2011). The first involves the ultimate authority that the original understanding properly exerts. Strict originalists maintain that the Supreme Court should always decide cases in accord with the original understanding. See, e.g., Randy E.
} 
Unequivocal historical arguments about the original understanding of constitutional language often make me nervous. To begin with, the question whether congressional power to require the purchase of health insurance falls within the original understanding of the commerce power may well have no answer as a matter of historical fact. The founding generation never confronted that or any similar question. Any direct response may require speculation about what imagined, hypothetical members of the founding generation would have said or thought if provided with more or less information about why a remote future generation might wish to enact a national insurance mandate. ${ }^{19}$

Beyond that problem, constitutional law professors might offer a number of potentially pertinent observations about the founding generation's thought and expectations concerning congressional power under Article I. Among them would be these: (1) A resolution of the Constitutional Convention that the Committee of Detail sought to implement when it drafted the various provisions of Article I, including the Commerce Clause, provided that Congress should have power "to legislate in all cases for the general interests of the Union, and also in those to which the States are separately incompetent." ${ }^{20}$ (2) The Constitution's authors and ratifiers intended to create a national government of limited powers only, with many of the most important regulatory responsibilities reserved to the states. ${ }^{21}$ (3) The members of the founding generation could not have imagined Congress mandating the purchase of health insurance. ${ }^{22}$

The brief that I was asked to sign emphasized the first of these three strands of relevant evidence and essentially ignored the other two. In my view, its argumentation fell well within the bounds of what lawyers could permissibly say in a brief. The brief was informative. In addition, I find its larger argument that the national health care mandate should be judged constitutional when seen in the broad sweep of American legal

Barnett, Trumping Precedent with Original Meaning: Not as Radical as It Sounds, 22 Const. CommENT. 257, 269 (2005). Others believe that the original understanding, insofar as it can be ascertained, is relevant but not necessarily decisive. The second debated question involves exactly what historians should look for or at in identifying the original understanding or original public meaning. Most self-styled originalists appear to believe that inquiry should aim at identifying how linguistically competent and otherwise wellinformed members of a prior generation would have understood constitutional language's specific bearing on modern issues. See, e.g., Vasan Kesavan \& Michael Stokes Paulsen, The Interpretive Force of the Constitution's Secret Drafting History, 91 GeO. L.J. 1113, 1132-33 (2003); John O. McGinniss \& Michael Rappaport, Original Interpretive Principles as the Core of Originalism, 24 CONST. COMMENT. 371, 374 (2007). By contrast, most non-originalists, including me, tend to believe that both history and constitutional adjudication are more complex, messy, and sometimes conflicted than originalists typically acknowledge and that a multitude of historical facts are potentially pertinent.

${ }^{19}$ See, e.g., McGinniss \& Rappaport, supra note _ , at 374 (asserting that "the focus of originalism should be on how a reasonable person at the time of the Constitution's adoption would have [understood] its words and thought they should be interpreted").

${ }^{20} 2$ RECORDS OF THE FEDERAL CONVENTION 21 (Max Farrand ed., 1911).

${ }^{21}$ The Tenth Amendment to the Constitution succinctly summarizes this understanding: "The powers not delegated to the United States by the Constitution, nor prohibited by it to the States, are reserved to the States, respectively, or to the people.”

${ }^{22}$ See generally JACK N. RAKOVE, ORIGINAL MEANings (1996) (emphasizing the failure of the founding generation to foresee or resolve many of the constitutional questions arising in later generations). 
history - in which an expansive interpretation of the Commerce Clause has emerged as a functional necessity-wholly persuasive. Nevertheless, I declined to join the brief, even though a number of the constitutional law professors whom I most respect made a different choice. The brief's presentation of the historical evidence bearing on the original understanding was not nuanced or balanced. A purportedly scholarly book or article that asserted its claims without further qualification would attract derision as onesided if not misleading.

This observation leads to a further comment that may surprise the uninitiated: Many scholars' briefs are actually not very scholarly. When drafted by law professors nearly as often as when written by practicing lawyers, scholars' briefs tend to be rather ordinary briefs that most commonly make the same arguments as the brief for the party that they support. ${ }^{23}$ As previous comments will have signaled, this is a generalization, not a categorical truth. Scholars' briefs occasionally rise to the level of magnificence. ${ }^{24}$ Nevertheless, briefs written to win the agreement of large numbers of lawyers (as law professors are) tend to get flattened out to the lowest common denominator. Among law professors, the lowest common denominator is likely to be relatively standard, lawyerly argument.

Like the recognition that a brief overreaches my actual expertise, the thought that my joining a brief would associate my name with claims that I would not make in a book or law review article strikes me as a reason meriting pause. If I am to identify myself as a scholar by signing a "scholars' brief," or as a professor who is an expert in the field and interested only in the proper development of the law, ought the brief not satisfy the norms of scholarly integrity to which we hold books and law review articles?

Maybe, but to say that a thought should give pause is not to say that it necessarily ought to prove decisive. As noted above, there are snippets of evidence suggesting that judges, Justices, and their clerks may look at scholars'

\footnotetext{
${ }^{23}$ An often expressed worry about amicus briefs in general, if not of scholars' briefs in particular, is that they may be orchestrated by the parties to a case as a means of overcoming page limits on parties' briefs. See, e.g., Glassroth v. Moore, 347 U.S. 916, 919 (11 ${ }^{\text {th }}$ Cir. 2003). A much-much cited article, Samuel Krislov, The Amicus Curiae Brief: From Friendship to Advocacy, 72 YALE L.J. 694, 695 (1963), argues that the typical function of amicus curiae briefs evolved "from neutral friendship to partisan advocacy" during the nineteenth century. A more recent study that relies heavily on a computerized search of cases included in searchable databases, Stuart Banner, The Myth of the Neutral Amicus: American Courts and Their Friends, 1790-1890, 20 CONST. COMMENTARY 111 (2003), revises the long-accepted picture. According to Banner, "[t]here was never a time in American practice when an amicus was only allowed to offer neutral advice." Id. at 113. Although "[t]here were more neutral than partisan amici in 1790-1820," id. at 119, "[a]fter 1831-40 the percentage of amici who were neutral never rose above $18 \%$ in any decade." Id.

${ }^{24}$ I think, for example, of the brief filed by my colleague Laurence Tribe, among others, in the gay-rights case of Romer v. Evans, 517 U.S. 620 (1996), and the "Philosophers' Brief" filed by the lawyerphilosopher Ronald Dworkin, among others, in two cases involving claimed rights to physician-assisted suicide, Washington v. Glucksberg, 521 U.S. 702 (1997), and Vacco v. Quill, 521 U.S. 793 (1997).
} 
briefs with greater interest than other amicus briefs. ${ }^{25}$ The literature on amicus curiae briefs - the larger category of which scholars' briefs are a subspecies-

finds that amicus briefs have the capacity to help the causes that they promote. ${ }^{26}$ When other law professors solicit my participation in amicus briefs, they frequently begin by saying that they would not ask me to join if the case were not unusually important. Consequences matter to me. Mulling whether to participate in a scholars' brief that advocates a result that I am disposed to favor, I thus feel both temptation and sometimes even moral pressure to join, even though doing so would also leave me uneasy, for reasons involving instincts about obligations of scholarly integrity.

\section{Contrasts between Scholars and Other Interested Parties and Lawyers for Clients}

Issues about the standards that law professors should apply in determining whether to sign scholars' briefs may begin to crystalize if we think of distinctions or contrasts along both of two dimensions. One involves a comparison of law professors with other organizations and individuals in whose names amicus briefs are filed. The other involves a juxtaposition with lawyers who author briefs, including amicus briefs, on behalf of individuals or organizations other than themselves.

\footnotetext{
${ }^{25}$ See supra notes ___ and accompanying text. But cf. Lynch, supra note _, at 53 (reporting that some Supreme Court law clerks "recounted a wariness of amicus briefs filed by large groups of law professors"). Even when scholars' briefs are not substantively distinctive, perhaps they give assurance to some judges or Justices that a number of experts in the relevant field believe that a particular result might actually be compelled by, or at least would fit into without too much disrupting, the overall fabric of the law. It is sometimes said that judges and Justices are influenced by elite opinion. See, e.g., Michael J. Klarman, From Jim Crow to Civil Rights: THE Supreme CourT AND THE STRuggle FOR RACial Equality 6 (2004); LuCAS A. Powe, THE Supreme Court AND the AmeriCAn Elite, 1789-2008 ix (2009). Perhaps it matters to them, consciously or subconsciously, how legal elites line up. If scholars' briefs provide a good measure of anything, it may be how particular decisions would likely fare in subsequent academic commentary.

${ }^{26}$ See Joseph D. Kearney \& Thomas W. Merrill, The Influence of Amicus Curiae Briefs on the Supreme Court, 148 U. PA. L. REv. 743, 830 (2000); Paul M. Collins, Jr., Friends of the Court: Examining the Influence of Amicus Curiae Participation in the U.S. Supreme Court, 38 L. \& SoC’Y REV. 807, 822 (2004). Kearney \& Merrill summarize their leading findings as follows: "that amicus briefs supporting respondents enjoy higher success rates that do amicus briefs supporting petitioners; that small disparities of one or two briefs for one side with no briefs on the other side may translate into higher success rates but larger disparities do not; that amicus briefs cited by the Court appear to be no more likely to be associated with the winning side than briefs not cited by the Court; and that amicus briefs filed by more experienced lawyers may be more successful than briefs filed by less experienced lawyers."

In crude summary, the literature divides into two camps in accounting for how amicus briefs achieve influence. Some scholars hypothesize that courts care about, and that amicus briefs signal, how various potentially affected constituencies view disputed legal issues. See id. at 785 (summarizing but not endorsing the interest-group theory view that " $[t]$ he fact that the organization saw fit to file the brief is the important datum, not the legal argument or the background information set forth"). The other theory holds that amicus briefs achieve influence by providing information and arguments that the parties do not supply. See, e.g., Simard, supra note _, at 682, 690-91. Kearney \& Merrill's empirical study of Supreme Court cases involving amicus briefs finds some support for the former theory but more for the latter, see Kearney \& Merrill, supra, at 830, as does Collins, supra, at 822.
} 


\section{A. Grounds of Interest in the Outcome of Litigation}

Should law professors, in filing amicus briefs, feel subject to any argumentative constraints that would not apply to other amici curiae? In weighing this question, it may help to consider how law professors who participate in scholars' briefs represent themselves to a court and how their representation compares with that offered by other parties on whose behalf amicus briefs are filed. Before filing a brief in the Supreme Court, a would-be amicus curiae who does not have the unanimous consent of the parties must seek leave to do so. ${ }^{27}$ And in seeking leave, would-be filers must disclose the nature of their "interest" in the case. ${ }^{28}$ Amici curiae in the courts of appeals must always include a statement of their interests. ${ }^{29}$ Perhaps what law professors owe the court when they submit scholars' briefs depends partly on what they represent to the court in their statements of interest.

Some parties seeking leave to file amicus briefs have, and assert, material or financial interests in the outcome of litigation. The assertion of a material interest signals that a party's brief will offer zealous but self-interested advocacy. Law professors filing scholars' briefs obviously stand on a different footing, which they hope and expect that a court will bear in mind when assessing their arguments. Many if not most scholars' briefs begin with assertions that the amici have no material interest in the outcome and that their sole interest involves the proper development of the law. Even absent such assertions, representations of expertise and disinterestedness typically seem implicit. ${ }^{30}$

\footnotetext{
${ }^{27}$ See Sup. Ct. R. 37.

${ }^{28}$ See id.

${ }^{29}$ Fed. R. App. Proc. 29.

${ }^{30}$ There may be a few cases in which law professors have material interests or close analogues thereto-for example, cases involving tenure or pension rights. In such cases, I see no reason why groups of law professors could not participate in amicus briefs in which they declared their material interests and in which counsel presented any available argument permitted under applicable rules of legal ethics. But it would be misleading for the participants in such a brief to designate themselves as legal scholars seeking disinterestedly to promote integrity in the development of the law. Cases presenting more complex issues about whether and to what extent law professors filing amicus briefs would implicitly present themselves as disinterested would be ones that arguably affect their capacity to function effectively as scholars and teachers. Examples would include those involving rights relating to teaching, scholarship, and the confidentiality of academic communications. See, e.g.,University of Pennsylvania v. EEOC, 493 U.S. 192 (1992) (ruling that the First Amendment does not shield universities' peer review files from disclosure in employment discrimination cases). In such cases, law professors may possess special insights gained from experience, but they are unlikely to be disinterested, and the reader of an amicus brief by law professors could not reasonably think otherwise. In my view, a similar analysis applies to the multiple amicus briefs filed by law professors in Rumsfeld v. Forum for Academic and Institutional Rights, Inc., 547 U.S. 47 (2006), which held that a statute requiring law schools to provide equal access to military recruiters despite the military's then-applicable “don't ask, don't tell” policy did not violate the schools' rights to freedom of speech and association. Most of the briefs sought recognition of rights for the institutions at which the amici taught and with which their interests were aligned. A brief on behalf of forty faculty members at Harvard Law School, which I joined, argued that the even-handed enforcement of an anti-discrimination policy against military recruiters along with all other recruiters actually did not violate the statute in question when that statute was properly interpreted and that there was, accordingly, no need for the Supreme Court even to reach the constitutional question in the case. See Brief of William Alford et al.,
} 
Another possible ground of interest for a group or individual that wants to file an amicus brief involves political or ideological commitments. Examples come from such organizations as the Sierra Club, the American Civil Liberties Union, the National Rifle Association, and the Heritage Foundation. Although there are obvious differences between organizations such as these and relatively ad hoc collections of law professors, there are similarities, too. In the constitutional law and federal courts cases in which I am asked to participate in scholars' briefs, many of the issues are politically charged. Once again, however, I am quite sure that most law professors filing scholars' briefs would vehemently deny that the reason a court should listen to them relates to their political ideologies. ${ }^{31}$ To the contrary, the reason to claim scholarly or professorial status through a designation such as "scholars' brief" is to represent oneself as having a distinctive expertise that depends on notions of integrity that are internal to the scholarly enterprise. Someone claiming scholarly expertise thus sets herself apart from those seeking to participate in a case based on ideological interests. Professors who join scholars' briefs aim to engender distinctive, role-based expectations concerning the character of their participation.

\section{B. Contrasts Between Scholars' Ethical Obligations and Those of Lawyers for Clients}

In contrasting law professors whose names appear on scholars' briefs with lawyers acting as advocates for clients, I take it for granted that law professors who are members of the bar are entitled to engage in client representation. Although it is possible to imagine arguments that the role of the law professor is somehow inherently incompatible with that of an advocate for clients, law schools are professional schools, and virtually no one believes that law professors should distance themselves so far from the legal profession. ${ }^{32}$ I further assume-for reasons that I shall explain more fully below-that law professors who engage in client representation have ethical obligations to engage in zealous advocacy that may not only permit, but actually compel, them to

2005 U.S. S. Ct. Briefs Lexis 630. In my view, the first two sentences of the section of that brief headed "Interests: The Interest of Amici Curiae" implicitly acknowledged that the signatories sought to promote goals that had their origin outside the law and that the amici did not pretend to offer purely disinterested scholarly expertise: “Amici are full-time faculty members at Harvard Law School. We are deeply committed to a fundamental moral principle: "A society that discriminates based on sexual orientation-or that tolerates discrimination by its members-is not a just society."” Id. But see Richard A. Posner, A Note on Rumsfeld v. FAIR and the Legal Academy, 2006 SUP. CT. REV. 47, 52 (asserting that "the professors were not parties to Rumsfeld $v$. FAIR and so a reader of their amicus curiae brief might expect the views expressed in it to represent their best professional judgment on the meaning of the Solomon Amendment" and further opining that “the Harvard professors' statutory argument bordered on the frivolous”).

${ }^{31}$ Cf. Voices for Choices v. Ill. Bell Tel. Co., 339 F.3d 542, 544 (2003) (Posner, J.) (“[T]he filing of an amicus brief is often an attempt to inject interest group politics into the federal appeals process.”).

${ }^{32}$ I do, however, know of a number of law professors who refuse to do consulting work on the ground that it might influence or give the appearance of influencing the views that they take in their scholarship and teaching. The more standard view, which I share, is that not all client representation poses these risks. For discussion of the possibility that some does, see infra. 
make arguments that they would not assert in scholarly books or articles. ${ }^{33}$ But professors who join amicus briefs either present themselves as clients, whose interests the lawyers formally designated as counsel represent, or in a complex mixture of the roles of lawyer and client. In either case, law professors joining scholars' briefs claim a distinctive interest in having the court resolve a case correctly as measured by legal standards that are at least partly independent of ideological views or preferences.

Law professors considering whether to join scholars' briefs thus cannot claim that they can ethically conscientiously join any brief that a lawyer representing a client could ethically conscientiously sign. When law professors present themselves as scholars, it becomes relevant that standards of integrity in scholarship differ from those applicable to legal advocacy by lawyers on behalf of clients. ${ }^{34}$

The standards of integrity applicable to lawyers representing clients typically have canonical statements in codes of professional responsibility or professional ethics. ${ }^{35}$ With respect to scholarly integrity, it is harder to find canonical statements of undoubted authority. Many universities have ethical codes. The American Association of University Professors adopted a Statement of Principles on Academic Freedom and Tenure in $1940^{36}$ and a Statement of Professional Ethics in 1966 that was revised by the Association's Council in 1987 and 2009. ${ }^{37}$ In addition, the Association of American Law Schools has issued a Statement of Good Practices by Law Professors in the Discharge of Their Ethical and Professional Responsibilities, most recently amended in 2003, albeit with the proviso that it is not intended to function as "a disciplinary code." 38 In contrasting standards of integrity for lawyers with those applicable to scholars, I rely partly on the AAUP and AALS statements, but even more on what I take to be understandings that are, and in my view ought to be, widely shared among law professors. My methodological assumptions here are thus "interpretive" in Professor Dworkin's sense of that term ${ }^{39}$ : My conclusions reflect a conscientious but contestable and potentially controversial effort to identify principles that would explain and support practices by law professors and others in judging legal scholarship and the performance of those who produce it.

\footnotetext{
${ }^{33}$ For further discussion of this assumption, see infra note _ and accompanying text.

${ }^{34}$ I put to one side all questions involving the obligations of lawyers who are not law professors in all roles other than client representation. In many roles-including that of expert witness, for example-a practicing lawyer's obligations of integrity may be identical to those of a law professor in producing legal scholarship. But there may, or may not, be differences in some other roles. I put aside questions of lawyers' obligations in roles other than that client representation not because they are uninteresting or unimportant, but because they are too multifarious and far-ranging for me to address in this article.

${ }^{35}$ See, e.g., American Bar Association, Model Rules of Professional Conduct (2010).

${ }^{36}$ Available at http://www.aaup.org/NR/rdonlyres/EBB1B330-33D3-4A51-B534CEE0C7A90DAB/0/1940StatementofPrinciplesonAcademicFreedomandTenure.pdf.

${ }^{37}$ Available at http://www.aaup.org/AAUP/pubsres/policydocs/contents/statementonprofessionalethics.htm.

${ }^{38}$ Available at http://www.aals.org/about_handbook_sgp_eth.php.

${ }^{39}$ See R. DWORKIN, LAW’s EMPIRE, supra note _, at 45-86.
} 
There are undoubtedly many contrasts between the standards of integrity applicable to lawyers representing clients and those applicable to law professors in their capacity as scholars. In my view, three have special significance.

First, a legal scholar presenting scholarly conclusions assumes individual responsibility for having authored any writing that she publishes under her name and for having done the research or performed the analysis on which her stated conclusions depend. ${ }^{40}$ This seems an important point of contrast with lawyers, who can rely on other lawyers to draft briefs that they sign.

Admittedly, specifying the precise norms of responsibility to which scholars are subject involves many complications. Of course a scholar can build on published work by others without having to re-do the research herself. In the view of scholars in other fields, legal scholarship characteristically includes excessive, unnecessary citations to prior, supporting literature. ${ }^{41}$ If nothing else, the prevailing norm with respect to citations helps enforce law professors' obligation to rely only on sources that they believe credible after duly diligent examination.

Similarly, no one doubts that a scholar can depend on the work of research assistants, including work done by them to document the truth of at least some claims. I behaved ethically-or so I believe-when I once trusted a research assistant to determine how many states have anti-abortion laws on their books that would become immediately operative if the Supreme Court overruled Roe v. Wade. ${ }^{42}$ Having received his report, I presented the information that he had discovered without repeating his 50 -state search. ${ }^{43}$ I offer this example because it may indicate that the precise scope of permissible reliance on research assistants is unquestionably debatable. Some may think I failed to do all that I responsibly ought to have done. I also know of colleagues who place further reliance on research assistants than I do and, in my judgment, go too far. Nevertheless, a vast terrain of the clearly impermissible bounds the zone of reasonable disagreement. I cannot ask a research assistant to write an article and then present it as my own. What is more, I trust research assistants at my peril. Any failure by a research assistant on whose work I rely is one for which I must accept responsibility.

Co-authorship introduces yet another complexity, the relevant details of which may vary from one academic discipline to another. I do not presume to speak, for example, of scientific publications resulting from research conducted by large teams. In

\footnotetext{
40 "Responsibility" is a complex, multifaceted concept. See RonAld DWORKIn, JusticE FOR HedgeHOGS 102-04 (2011). My use of the term corresponds most nearly to what Dworkin calls "intellectual responsibility." See id. at 102 ("A scientist who does not check his calculations lacks intellectual responsibility.") But I believe that the obligation of a scholar to make only such assertions as she is able to support with research or personal analysis includes elements of what Dworkin calls "ethical" and "moral" responsibility. See id. at 102-03.

${ }^{41}$ See, e.g., Laura Kalman, The Constitution, the Supreme Court, and the New Deal, 110 AM. HIST. REV. 1052, 1074 (2005).

42410 U.S. 113 (1973).

${ }^{43}$ See Richard H. Fallon, Jr., If Roe Were Overruled: Abortion and the Constitution in a Post-Roe World, 51 ST. LouIs. U. L.J. 611, 614 (2007).
} 
legal scholarship, however, co-authors implicitly present themselves as partners who testify publicly to one another's scholarly capacity and integrity. In co-authoring an article or book, I can rely on my co-author to have done trustworthy research, not all of which I have necessarily performed myself. But I would be grievously at fault for choosing a co-author who was not intellectually trustworthy to conform to high scholarly standards. Upon reflection, I also believe that when co-authors divide the work for collaborative projects, they should be as forthcoming as reasonably possible about who takes principal responsibility for what. In the past, I have not always satisfied this standard myself, and I do not claim that it is widely recognized, even with respect to casebooks, in which it is common for one co-author to do most or all of the work for some chapters and another co-author for others. Be that as it may, in cases involving coauthorship, a legal scholar implicitly represents that if she has not done adequate work to support all of the claims and conclusions that her book or article presents, then her coauthor has, and that she has a sound basis in personal knowledge for choosing to trust her co-author.

Second, when a scholar publishes a book or article, she is subject to a norm of trustworthiness, which demands that she sincerely believe all of her claims or arguments and that she state them in ways not intended to mislead her readers about their relation to other arguments or evidence. ${ }^{44}$ In order to advance an argument on one point, a scholar cannot make claims that she would disavow or recant in another context with the explanation that she made the contrary assertions only for the instrumental purpose of persuading a particular audience and that she had never really believed what she said.

To clarify the scope of what is at stake here, it may help to draw an admittedly wobbly but nevertheless useful distinction between claims purporting to report what I shall call the "plain truth" and those that reflect more normatively influenced judgments. ${ }^{45}$ As I shall use the term, statements of plain truth are true (if they are true at all) as a matter of fact on which all fully informed observers in a particular social context could be expected to agree ${ }^{46}$ —or, if they did not agree, should think that they needed to

\footnotetext{
${ }^{44}$ For a somewhat different account of trustworthiness, but one that has influenced both my use of the concept and some of my normative analysis in this essay, see W.T. Jones, Public Roles, Private Roles, and Differential Moral Assessments of Role Performance, 94 ETHICs 603, 607 (1984) (characterizing "trustworthiness" as the distinctive virtue of private as distinguished from public roles, in which the principal virtue is "effectiveness").

${ }^{45}$ The concept of truth is marvelously perplexing. See generally Michael Glanzberg, Truth, STANFORD ENCYC. PHIL. (2009). Among the difficulties with developing any deep distinction between what I am calling "plain" truth and other more commonly contested claims of truth, what counts as a "fact" may depend on theory-laden assumptions, there may be irreducible indeterminacies in attempts to "translate" assertions made in one language into another language, and the distinction between "analytical" or logical claims and those of asserted empirical fact may be unstable. I do not believe that these deep complications threaten my suggestion that for nearly all everyday purposes we have no difficulty in identifying matters of plain truth on which all informed and competent people ought to agree.

${ }^{46}$ So used, the notion of plain truth encompasses both what JoHn SEARLE, SPEECH Acts: AN ESSAY IN THE PHILOSOPHY OF LANGUAGE 34-35 (1969) characterizes a "brute facts," which do not depend on social conventions or practices, and "institutional facts," which do.
} 
offer an explanation for adopting a non-standard view. ${ }^{47}$ In law, these include such matters as the text of the Constitution, statutes, and judicial opinions; many historical facts pertinent to legal analysis; and at least some elements of descriptions of what courts and other authorities - including empirical, scientific, and social scientific studies - have said, held, or established.

By contrast with matters of plain truth, many assertions about how legal questions ought to be resolved as a matter of law in light of pre-existing authorities predictably and understandably arouse disagreement. Often, if not always, such disagreement reflects divergent views about which outcome would be normatively best. Disagreement of this kind can involve both the appropriate "interpretation" of authorities ${ }^{48}$ and the best "implementation" of general norms via doctrinal tests and judicially manageable standards (to take just two examples). ${ }^{49}$ Nevertheless, the fact of disagreement does not exclude the possibility that some conclusions can be better supported or better reasoned than others. Among other things, good legal arguments need to identify and reckon honestly with a sometimes broad range of pertinent authorities.

With respect to matters of plain truth, lawyers filing briefs and making arguments to courts have obligations of truth-telling that are similar if not identical to those of scholars. ${ }^{50}$ With respect to interpretive matters or those otherwise calling for an exercise of judgment, I think it is and ought to be widely accepted that a scholar asserting conclusions should have done her conscientious best to weigh all relevant considerations and to reach a judgment that she is prepared sincerely to defend as supported by the overall balance of reasons. ${ }^{51}$ By contrast, lawyers arguing on behalf of clients need not certify their personal, good faith belief that their arguments are more accurate or persuasive than other available arguments. ${ }^{52}$ The lawyer who represents a client plays a role in which all informed observers understand that she does not pretend to speak as a disinterested seeker after truth or sincere believer in all that she says. Indeed, a lawyer would be derelict in her professional obligations if she failed to make the legally colorable arguments that would give her clients the best chance to prevail merely because she had determined that a judge would err in accepting them.

\footnotetext{
${ }^{47}$ For example, someone who holds the view that (what others call) the Fourteenth Amendment is not really part of the Constitution because it was not properly ratified ought to know she should explain if asserting as a matter of fact to someone who was otherwise uninformed about the matter that only two Amendments were adopted during the Reconstruction era.

${ }^{48}$ See R. DWORKIN, LAW'S EMPIRE, supra note _, at 225-75.

${ }^{49}$ See RichARD H. FALLON, JR., IMPLEMENTING THE CONSTITUTION 36-42 (2001).

${ }^{50}$ See ABA Model Code of Professional Conduct, supra note __, Rule 3.3 ("Candor Toward the Tribunal”).

${ }^{51}$ I do not mean to be making any controversial jurisprudential claim about how a legal scholar should assess the weight of any one reason in comparison with another. Sometimes a scholar may conclude that preexisting authorities dictate a result that otherwise would be undesirable; sometimes the overall balance of reasons may yield the conclusion that current doctrine should be changed. My only claim is that legal scholars should assert only such judgments as they can sincerely defend under whatever jurisprudential assumptions they embrace.

${ }^{52}$ A lawyer may owe obligations of trustworthiness to her clients that she does not owe to those whom she addresses in her capacity as a representative of the client. I speak here only of the lawyer's responsibilities in the latter role.
} 
Third, norms of scholarly integrity applicable to legal scholarship include an obligation - which partly overlaps that of integrity and might even be subsumed by it if integrity were sufficiently capaciously construed-that I shall call confrontation. The confrontation norm requires scholars to be candid in acknowledging difficulties with their arguments by confronting the most significant possible non-obvious objections to their analyses. Implicitly, at least, scholars publishing books and articles represent that they have not covered up any pertinent facts bearing on issues of plain truth. But I believe that the obligation goes further. A scholar should not fail to acknowledge counter-arguments that others reasonably might find telling if they knew or thought of them. ${ }^{53}$ What is more, a scholar should put the counterarguments as clearly and as fairly as she can before explaining why she ultimately finds them unpersuasive.

Once again, many complexities surround this point. No legal scholar invariantly satisfies all scholarly ideals to the fullest extent. Even when trying our best, we all are fallible. Some otherwise creditable scholars may fail to see the force of objections because they have not framed them clearly and imaginatively, even in their own minds. No one is excluded from the category of "legal scholar" as a result of having failed to fulfill the "confrontation" norm, or the others either, to the greatest possible degree. Nevertheless, the best scholarship distinguishes itself partly by displaying depth and sophistication in meeting the hardest challenges head-on. And any willful concealment of difficulties is seriously culpable.

Another strong contrast with lawyers authoring briefs emerges here. Although lawyers cannot misrepresent the plain truth, and should divulge to the court any authorities "directly adverse to the position of the client," 54 they do not need to reveal what they may regard as other vulnerabilities in their arguments. Doing so may often be good tactics. Good lawyers will frequently want to anticipate counter-arguments in order to refute them. But whether to do so is a tactical question, not one involving moral or ethical obligations of trustworthiness or confrontation.

Before concluding this discussion of contrasts between the obligations of scholars and those of lawyers writing briefs, I should say a special word about so-called "advocacy scholarship," in which an author attempts to craft an argument expressly aimed at persuading courts or at furnishing a template for practicing lawyers involved in litigation. Even in this case, the contrast between scholars and lawyers for clients holds. To be sure, a professor writing an article in the advocacy genre may both cast and understand herself as performing a function unlike that of pure truth-seekers on faculties of arts and sciences. Nevertheless, scholarly norms such as those that I identified above remain unavoidable, even though they of course may be satisfied to greater or lesser degree. If a law professor who publishes an "advocacy" article in a law review cannot take personal responsibility for the underlying research and analysis, she has no business labeling the article as her own. If she will not vouch for at least the minimal

\footnotetext{
${ }^{53}$ See AALS, Statement of Good Practices by Law Professors, Sec. II ("Responsibilities As Scholars”), supra note _, ("Relevant evidence and arguments should be addressed.”).

${ }^{54}$ ABA Model Rule 3.3(a)(2).
} 
trustworthiness of her arguments, she can neither ask nor expect her readers to follow her to her conclusions. And if she does not identify and confront difficulties in her arguments, she puts those who credulously embrace them at risk of being caught in future argumentative traps from which they may not know how to escape. ${ }^{55}$

Thus, when measured against all three of the contrasts that I have now drawn between the obligations of scholars and those of lawyers writing briefs, requests to sign amicus briefs often put strains on standards of scholarly integrity. In saying so, however, I of course refer to the standards applicable to scholars writing books and articles. Nothing that I have said yet conclusively rules out the possibility that law professors should conform to different standards when writing or deciding whether to join amicus briefs.

\section{Law Professors’ Role-Based Obligations}

Much of my analysis so far has assumed the relevance of role-based morality: Moral obligations and ethical constraints sometimes vary with the role in which a person acts. $^{56}$ To recur to the contrast between practicing lawyers and law professors, lawyers who have assumed responsibilities of client representation are subject to one set of constraints, scholars publishing journal articles to another. On the one hand, a lawyer has special obligations to her clients. On the other, once the role of the lawyer has become settled enough to establish expectations concerning lawyers' duties of zealous representation, we cannot reasonably accuse a lawyer of behaving dishonestly or betraying a court's trust by offering arguments that she believes unpersuasive.

The latter point merits pausing over. Although it is easy to see how roles can create obligations that would not otherwise exist, it may be more difficult to explain how roles can render permissible what otherwise would be impermissible. Surely the role of Mafioso cannot create a permission to commit murder. Similarly, some think that lawyers commit moral wrongs by pressing arguments that they know or believe to be fallacious. ${ }^{57}$ But there is an important distinction between the Mafioso and the lawyer. The purported "role" of the Mafioso has no plausible moral justification. By contrast, I assume the adversary system to be a reasonably just mechanism for the resolution of legal

\footnotetext{
${ }^{55}$ A similar analysis should apply to scholarship that stakes out provocative positions in part simply to be provocative-for example, by attacking an assumption that has largely escaped challenge or by making the best possible case for an intriguingly counterintuitive idea. A law professor who sets out to be provocative may test the outer limits of trustworthiness, but surely cannot ignore or escape this constraint. A writer in this mode is, moreover, as bound as any other legal scholar by obligations of personal responsibility for what she writes and will be judged for compliance with scholarly norms requiring confrontation of nonobvious difficulties in arguments.

${ }^{56}$ The point should not be overstated. Among other things, "[r]ole is not a well-defined and welldeveloped moral idea, and we shall have to make do with some sloppiness around the edges.” ARTHUR Isak Applbaum, Ethics for Adversaries: The Morality of Roles in Public And Professional Life 46 (1999).

${ }^{57}$ See A. APPLBAUM, supra note —, at 109 ("Roles do not overwrite moral prohibitions with moral permissions.").
} 
disputes, even though other mechanisms might also be reasonably just. ${ }^{58}$ If so, then the roles that the adversary system creates-like those created by other reasonably just institutions - can confer at least some moral permissions. ${ }^{59}$ To take the plainest examples of reasonably just institutions making permissible what otherwise would be impermissible, the legal system can convert what otherwise would be theft into taxation and what otherwise would be kidnapping into conscription or criminal incarceration. In sum, above some threshold of institutional justification, the definition of moral wrongs, as well as entitlements, often depends partly on the structure of social institutions that might be otherwise. ${ }^{60}$

Against the background of role-based morality, an obvious question is whether there is a relevant, well-defined social role of "signer of scholars' briefs" that reflects and generates justified public expectations of what one permissibly can and cannot do in that capacity. If there were such a role, and if the obligations and constraints that define it had adequate justification, then I assume it would be morally acceptable for a law professor to act within it. Although I shall say more about this possibility below, I think it plain enough that no well-recognized and morally defensible role of "law professor as signer of scholars' briefs” has yet emerged. Moreover, even if some or possibly many law professors now think themselves justified in joining any briefs that they could sign as lawyers representing clients or submit as representatives of organizations with ideologically defined missions, it would still be possible, at this stage, to reject that conclusion as mistaken if it were too out of joint with other, better supported judgments about law professors' role-based obligations.

Again, however, I do not mean to be too quick to reach ultimate conclusions. In assessing how law professors ought to think about whether and when to join scholars' briefs, it will help, next, to reflect briefly on the general character of moral and ethical standards and on the norms applicable to other roles that law professors occupy (such as those of author of scholarly books and articles, teacher, and lawyer for clients). Having done so, we will be better situated to gauge the obligations of law professors who are asked to sign scholars' briefs in light of both a general view of the nature of moral and ethical obligation and specific, grounded judgments about law professors' obligations in other roles.

\section{A. Moral and Ethical Constraints}

In ordinary parlance, the terms "moral" and "ethical" are typically used interchangeably. Philosophers, however, sometimes distinguish morality from ethicsor, perhaps more precisely, they treat "morality” as having narrower and broader senses,

\footnotetext{
${ }^{58}$ See DAVid LubAn, LAwYers AND Justice: An EthicAl Study 92-93 (1988) (justifying the adversary system on the "pragmatic" grounds that we need a system of adjudication, that the adversary system does a reasonably good job of finding truth and individual rights, that no rival would be clearly superior, and that the adversary system is the one that we happen to have).

${ }^{59}$ Luban, supra note _ , at 132-33, 138, argues forcefully that where the justification for an institution and the roles that is creates is relatively weak, the potential exists for conflicts between role-based and ordinary moral obligations, and that in the case of such conflicts, the latter need not always prevail.

${ }^{60}$ See supra note _ and accompanying text.
} 
the narrower of which is distinct from and the broader of which subsumes "ethics.",61 When morality and ethics are so distinguished, morality, in the narrower sense, refers to the domain of what we owe to each other. ${ }^{62}$ Ethics, by contrast, refers to the domain of standards bearing on how we ought to live in order to lead good or worthy lives. ${ }^{63}$ The recognition of a domain of ethics distinct from that of morality has greatest pertinence if we assume that we are entitled to make judgments concerning how to live that are not dictated in every particular by the obligations that we owe to others as a matter of impersonal morality.

Following Thomas Nagel, I believe that morality-here using the term in the narrower sense-involves two kinds of demands that can sometimes exist in tension, and possibly conflict, with one another. ${ }^{64}$ One set of demands reflects the significance of consequences. ${ }^{65}$ If we can realize highly desirable consequences at relatively little cost to ourselves, or avert significant harms to others, then we ought to do so. The other set of demands or constraints, which are often characterized as "deontological," involves duties to others that are specified independently of the good that we might accomplish or the harm we might avert. ${ }^{66}$ Many if not most of these demands manifest themselves in constraints on the ways that we can permissibly treat other people. For example, it is normally wrong to inflict harm deliberately on people or lie to them or betray their trust even when we might achieve some otherwise good end by doing so. In a hypothetical case much discussed by philosophers, a doctor cannot permissibly kill one patient in order to harvest organs that could save five others. ${ }^{67}$

Although the claims of consequentialist and deontological morality can apply to everyone in all facets of life, the precise nature and relative strength of their claims can vary with the role that one occupies. Nagel says that the more public the role, the larger the claims of concerns about consequences. ${ }^{68}$ A president may permissibly order the lies and betrayal that espionage requires, and a spy in the service of a nation at risk may lie and betray, with claims of deontological morality relaxing at least somewhat.

The ethical question of how one ought to live is also richly multi-faceted. There is no single right way for everyone. For the most part, people who enter a morally permissible profession or professional role should, as an ethical matter, attempt to perform well in that role. When roles are in flux, or no stable social understanding establishes how those acting in the role can reasonably be expected to perform, it may be an ethical question, as well as a moral one, how to construe or interpret the role or how to act within it.

\footnotetext{
${ }^{61}$ See, e.g., R. DWORKIN, JuSTICE FOR HEDGEHOGS, supra note _, at 13-15, 25, 150; BERNARD WILLIAMS, ETHICS AND THE LIMITS OF PHILOSOPHY 174-96 (1985).

${ }^{62}$ See R. DWORKIN, JUSTICE FOR HEDGEHOGS, supra note _

${ }^{63}$ See id.

${ }^{64}$ See, e.g., Thomas Nagel's, War and Massacre, Ruthlessness in Public Life, and The Fragmentation of Value, all reprinted in ThOMAs NAGEL, MORTAL QUESTIONS (1979).

${ }^{65}$ See T. NAGEL, MORTAL Questions, supra note _, at 54, 83.

${ }^{66}$ See id. See also Thomas Nagel, The View From Nowhere (1986).

${ }^{67}$ See, e.g., T.M. SCANLON, MORAL DimENSIONS: PERMisSiBILITY, MEANING, BLAME 15 (2008).

${ }^{68}$ See T. NAGEL, MORTAL QuESTIONS, supra note _, at 83-85.
} 
And, as I have suggested, there can also be ethical questions concerning which roles or sub-roles one ought to occupy or perform. For example, I am a law professor, which seems to me to represent an ethically defensible choice of vocation. But that vocation leaves many further choices open. In common with other law professors, I routinely confront issues about whether, for example, to spend more of my professional time on teaching or scholarship, on scholars' briefs, on paid or unpaid consulting work, or on non-scholarly publications. In these as in many matters, the line between morals and ethics may prove fuzzy in some cases. It is largely up to me to decide how best to allocate my professional time, but some choices could breach obligations that I owe to others, including judges, my law school, and my students. Other choices, even if they did not violate obligations that I strictly owe to others, might be ethically poor ones.

\section{B. Professors' Roles}

As I have recognized, law professors are not just scholars. The law professor is poised between the academy and the profession. If we think about the variety of roles that law professors play, perhaps we can make further progress toward identifying the moral and ethical constraints that bear specifically on their participation in scholars' briefs. $^{69}$ This approach will facilitate reasoning by analogy and permit a checking of tentative judgments in one domain against judgments and the principles that support them in other domains. Relevant roles include these:

Author of scholarly publications. Above I discussed some of the moral and ethical obligations of and constraints on law professors doing legal scholarship. ${ }^{70}$ Among other things, that discussion emphasized what I characterized as special obligations of responsibility, trustworthiness, and confrontation. In publishing scholarship, a law professor creates expectations among readers that she then owes it to them to fulfill. ${ }^{71}$ It is hard to imagine how anyone could defend a set of norms for legal scholars-even in wholly consequentialist terms-that did not define the scholars' role to include stringent obligations of responsibility, trustworthiness, and confrontation.

Teacher. Many of a law professor's most clearly and stringently defined obligations involve teaching. ${ }^{72}$ Professors must meet their classes, satisfy norms of professional conduct in the classroom, assign grades fairly and punctually, and much

\footnotetext{
${ }^{69}$ For a proposed set of "canons" applicable to some of these roles, see Robert B. McKay, Ethical Standards for Law Teachers, 25 ARK. L. REV. 44 (1971).

${ }^{70}$ AALS, Statement of Good Practices by Law Professors, supra note _, asserts in Section II, "Responsibilities as a Scholar," that "law professors have a responsibility to engage in their own research and publish their conclusions."

${ }^{71}$ See generally R. DwORKIN, HedgeHOGS, supra note _, at 304 (identifying a "general moral responsibility: not to harm other people by first encouraging them to expect that we will act in a certain way and then not acting in that way").

${ }^{72}$ See Section I of AALS, Statement of Good Practices by Law Professors, supra note _ (addressing law professors' "Responsibilities to Students"); Norman Redlich, Professional Responsibility of Law Teachers, 29 CleVE. ST. L. REV. 623, 625-26 (1980).
} 
more. ${ }^{73}$ Even beyond what appears in contractual or otherwise canonical statements of professorial obligations, obligations of responsibility, trustworthiness, and confrontation similar to those that attach to a law professor in the role of scholar apply to the role of teacher.

Although there are many ways to teach well, successful teaching of any kind requires trust. For a teacher to deserve trust, she must take personal responsibility for the accuracy or sincerity of what she says to her students (unless she makes clear, before or after the fact, that she is merely airing positions that deserve to be confronted) and should not cover up difficulties in her arguments. The role of teacher carries especially enhanced obligations of trustworthiness in counseling students about what to do or believe. Once again, I cannot imagine a remotely plausible set of role specifications for law professors that did not require them to hold themselves out to their students as trustworthy and then to requite the trust that they encourage their students to place in them.

Colleague. In performing institutional service and otherwise acting as a colleague, a law professor owes strict obligations of responsibility, trustworthiness, and confrontation. She should not assert propositions of what purport to be plain truth unless she reasonably and responsibly believes them to be true and should be sincere and forthcoming in offering arguments for or explanations of institutional decisions. Law professors' "paramount responsibilities" lie "within their institution[s]," 74 and these include obligations of institutional service and support for colleagues' teaching and scholarship. $^{75}$

Lawyer for clients. I said above that a law professor representing a client has the same-which is to say only the-obligations of responsibility, trustworthiness, and confrontation in asserting arguments on behalf of a client as does any other lawyer. A law professor who becomes a lawyer for a client does not, of course, cease to be a law professor, any more than any human being who becomes a lawyer sheds her other roles and the moral obligations that attend them. It is possible, moreover, for role-based obligations to come into conflict with one another. Insofar as there would be conflicts between one's obligations as a law professor and as a lawyer for a particular client, then one ought not take on the latter role ${ }^{76}$ - a matter that I shall discuss shortly. But in cases in which a law professor morally and ethically permissibly acts as a lawyer for a client at all, I do not believe that the distinctive role-based obligations of a law professor conflict with or dilute the distinctive role-based obligations and permissions of a lawyer representing a client within the adversary system.

\footnotetext{
${ }^{73}$ See Section I of AALS, Statement of Good Practices by Law Professors, supra note _ (addressing law professors' "Responsibilities to Students").

${ }_{75}^{74}$ AAUP, Statement of Professional Ethics, supra note _, para. 5.

${ }^{75}$ See AALS, Statement of Good Practices by Law Professors, supra note _, Sec. III of which ("Responsibilities to Colleagues") states that "[l]aw professors should make themselves reasonably available to colleagues for purposes of discussing teaching methods, content of courses, possible topics of scholarship, scholarly works in progress, and related matters."

${ }^{76}$ See Redlich, supra note _, at 629 (urging law professors to show discretion in deciding which clients to accept).
} 
This judgment rests on several admittedly contestable premises that I should attempt to clarify, even if I cannot defend them fully. As I have said already, I assume that the adversary system is a reasonably just institution; that within the adversary system, the role of the lawyer is widely understood to be that of zealous advocate, rather than disinterested seeker after truth; and that clients within the adversary system are entitled to zealous advocates. If so, one who opts into the role of zealous advocate within the adversary system undertakes obligations that at least normally overwrite otherwise applicable moral constraints that are inconsistent with the morally adequately justified obligations that the adversary system creates. And I see nothing about the peculiar role of the law professor that would put law professors who engage in client representation into a different category.

The intuitive support for this conclusion seems clearest if we think of the case of a law professor acting as a lawyer for an impecunious pro bono client. Such a client ought not be disadvantaged because her lawyer is a law professor. A law professor who could not represent the client as zealously as another morally and ethically conscientious lawyer ought not take on the representation. This example may seem to omit a crucial complication in most actual cases. Clients who seek law professors as counsel may hope to leverage the professors' scholarly reputation_-as something distinct from the professors' legal skills and insights-into a tactical asset. ${ }^{77}$ For example, the client may hope that the professor will possess unusual credibility. But credibility with respect to what? If lawyers who are not professors warrantee only that the positions that they take on behalf of their clients are legally tenable ones, not ones that they sincerely believe to be valid, it would be unreasonable to insist that a law professor arguing on behalf of a client should only assert claims that she would sincerely adjudge persuasive in her capacity as a scholar or teacher. With respect to some issues, a professor may not even know which arguments she would find most persuasive if she had encountered them first in a context not involving client representation. Perhaps more important, credibility is a crucial and potentially forfeitable asset for all lawyers, not just law professors, and it is by no means certain that a law professor will always enjoy an advantage over counsel for the other side. In litigation involving complex legal issues, a lawyer's credibility depends crucially on judges' believing that she has a broad-ranging knowledge of the pertinent authorities and can be trusted to characterize them in ways that are not misleading. Measured against this standard, some practicing lawyers may begin a case with more credibility than some law professors. And if assertions about particular authorities do not stand up when a judge or her law clerk personally examines them, a professor's credibility will presumably dissolve as rapidly as that of a full-time practitioner.

If law professors have the same obligations and permissions as other lawyers when acting in the role of client representative, it is a separate question, as I have indicated, whether there are possible moral and ethical constraints on a law professor's becoming involved in client representation in particular cases. Clearly a law professor

\footnotetext{
${ }^{77}$ See Redlich, supra note __, at 629 ("Law teachers should also be aware that whenever they engage in outside practice, it is highly likely that some one ... is benefiting from the professor's affiliation with a law school.”).
} 
ought not assume duties of client representation that conflict with her teaching obligations. A further question is whether it is morally problematic for a law professor, because of her obligations of responsibility, trustworthiness, and confrontation in her roles as scholar and teacher, to represent particular clients or clients who want to argue particular positions. With respect to this question, I believe that a law professor should feel morally obliged to say no to a request to represent a client in any case in which she thought that client representation would compromise her capacity to act with trustworthiness and to give forthright statements of her actual views in other roles-for example, because she might feel obliged to trim or alter the legal judgments expressed in future scholarship in order to retain the client's business. ${ }^{78}$ A law professor who compromised her scholarship in this way would violate obligations of professional priority that she owes to her law school and possibly of trustworthiness that she owes to those who read her scholarship. ${ }^{79}$

A further question is whether law professors ought to decline to represent particular clients or to argue particular positions, not because they would violate moral obligations to others by doing so, but because doing so is ethically unattractive. In my view, a law professor need not refuse to represent all clients whose positions on the merits she would not agree with (in her role as a scholar or teacher), but she ought not represent clients whose positions, if adopted, would have a significantly adverse effect on the trajectory of the law's development, as judged by the professor herself.

\footnotetext{
${ }^{78}$ See generally Rory K. Little, Law Professors as Lawyers: Consultants, Of Counsel, and the Ethics of Self-Flagellation, 42 S. TEX. L. REv. 345, 370 (2001) (“A real cost of outside expert consulting by law professors is that they may consciously decline to state strong opinions on some issues, for fear of providing material for their future impeachment ... or losing business .... If a professor's practice silences scholarship, it is an unmitigated bad for law professors and the profession.”); Rebecca S. Eisenberg, The Scholar as Advocate, 43 J. LEG. EDUC. 391, 393 (1993) ("There are reasons to question whether the academic views of legal scholars who do significant consulting are truly their own views, undistorted by the interests of their clients.").

${ }^{79}$ See, e.g., AAUP, Statement of Professional Ethics, supra note _ , para. 5: "Professors give due regard to their paramount responsibilities within their institution in determining the amount and character of work done outside it.” I also assume that a law professor should disclose any client representation or other paid relationships that others might reasonably think could influence her scholarly judgments or policy recommendations. See AALS, Statement of Good Practices by Law Professors, supra note _.: A law professor shall disclose the material facts relating to the receipt of direct or indirect payment for, or any personal economic interest in, any covered activity that the professor undertakes in a professorial capacity .... A law professor shall also disclose the fact that views or analysis expressed in any covered activity were espoused or developed in the course of either paid or unpaid representation of or consultation with a client when a reasonable person would likely see that fact as having influenced the position taken by the professor .... Covered activities include any published work, oral or written presentation in conferences, drafting committees, legislatures, law reform bodies and the like, and any expert testimony submitted in legal proceedings. A law professor should make, to the extent possible, all disclosures discussed in this policy at the earliest possible time.

A number of academic disciplines have codes of ethics mandating disclosures of this kind. For an influential argument that the academic economists should be subject to formal disclosure mandates of this kind, see Gerald Epstein \& Jessica Carrick-Hagenbarth, Financial Economists, Financial Interests and Dark Corners of the Meltdown: It's Time to Set Ethical Standards for the Economics Profession, Workingpaper Series No. 239, Political Economy Research Institute, Univ. of Mass. Amherst (Oct. 2010).
} 
A person who becomes a law professor adopts a role of reflecting thoughtfully and conscientiously on matters of legal policy and justice. If her scholarship is not purely descriptive, she takes on the role of attempting to promote the understandings that would lead to the best legal outcomes as defined by irreducibly normative criteria. A law professor who turned her back on that aspiration in a case involving substantial legal stakes that she herself recognizes, largely if not wholly to earn consulting dollars, would degrade and devalue her previously defining professional ethical choices, and sometimes those of her colleagues, in a way that a practicing lawyer arguing the same position in the same case would not. ${ }^{80}$

Advocate for law reform in ways other than client representation. Law professors often perform both honorably and admirably as advocates for law reform. If a law professor appears before members of Congress or a state legislature, we expect her to make arguments that will be accessible to and persuasive with an audience with limited time and attention and, one imagines, with limited patience for some kinds of rigorously scholarly analysis.

Insofar as trustworthiness is concerned, it may suffice for a law professor not to misrepresent the facts or law or make fallacious or misleading claims. When acting as an advocate for law reform, a law professor can surely present policy arguments without considering their relation to political and other arguments the politicians might care about.

With respect to confrontation, it matters that a law professor acting as a reform advocate will frequently lack control of the forum in which she appears and must take her audience, which she has only a brief time to try to persuade, as she finds it. Too much time devoted to exposing difficulties in her own argument could cause attempted advocacy not just to fail, but to backfire. At the same time, it matters that the professoradvocate is indeed a professor. The professorial role-to which the professor-advocate is likely to appeal implicitly, if not explicitly, in her claim to credibility-generates expectations of adherence to unusually high standards of intellectual rigor and candor, even if those expectations may be to some extent defeasible, as in cases in which a law professor appears as a lawyer for a client. Overall, the pinch is likely to feel tightest when a professor is asked to appear as a witness in a quasi-adversarial hearing in which she would be expected, on the one hand, to support the position of the side that has asked her to testify and, on the other hand, to speak with the integrity of a scholar, since it will inevitably be scholarly stature that results in a professor's being called as a witness in the first place. If a professor doubts that she can serve her cause effectively while also speaking honestly in response to challenges, then she should decline to testify.

Other partly forum-defined roles. Recognition that a law professor's obligations can vary with the forum in which she appears invites attention to the nearly boundless

\footnotetext{
${ }^{80}$ If there are law professors who purport to indifference about how any and all high-stakes cases ought to be resolved, their outlook is ethically impoverished and irresponsible.
} 
variety of fora in which law professors - identified as such-either speak or write. To name just a few examples, these can include letters-to-the-editor columns, debates before organizations of different types, sundry convocations of students from kindergarteners to advanced degree candidates, and retirement celebrations or memorial services for colleagues. Fora such as these pose diverse challenges. Audiences vary in their capacity to follow complex, nuanced arguments. Surely a law professor asked to speak about legal topics to grade-schoolers should not stand tongue-tied because young children cannot grasp the complexities that scholarly standards would demand in a law review article. Nor should a law professor appraising a colleague's teaching or scholarship in a retirement testimonial necessarily disclose all of the objections that critics might plausibly raise.

Given the range of fora in which law professors appear, and the differences that attributes of these various fora may make for the standards of integrity that law professors ought to observe, anyone who set out to draft a moral or ethical rulebook would embark on a fool's errand. Whatever the forum, professors bear at least a strong presumptive obligation not to deviate from the plain truth. When an audience reasonably expects a professor to satisfy high standards of scholarly trustworthiness and to identify and confront difficulties in her argument, the professor presumptively ought to do so, unless she clearly signals to her audience that she will justifiably play a non-scholarly role-as, for example, in a debate format in which a professor is asked to argue for a side in which she does not wholeheartedly believe. But there may be lower expectations in fora in which law professors are expected and understood to opine quickly, without opportunity for careful research and reflection. Blog postings may fall within this category. Most lunch and dinner table conversations surely do.

In thinking abut the obligations that law professors owe their audiences, there is no avoiding reference to reasonable expectations. Although that reference is partly circular, some circularity is inevitable if we accept that social roles shape expectations and that we have a "general moral responsibility[] not to harm other people by first encouraging them to expect that we will act in a certain way and then not acting in that way." 81 Think again of the law professor who is asked to pay tribute to a colleague at a retirement celebration or memorial service. As a wise colleague once said to me, "a testimonial is not an affidavit," and no one wants or expects it to be, even when it comes from a law professor with relevant professional expertise.

\section{Standards for Law Professors Signing Scholars' Briefs and Expressing Collective Professorial Opinions}

It is now time to be concrete about standards that law professors ought to observe in deciding whether to sign a scholars' brief that someone else has prepared. In this Part, I begin by making a few observations about the nature of a brief as a legal document. By practically necessary implication, I argue, the form of a brief may require some adjustments in the role-based standards of integrity that I identified in Part II.B as governing the production of legal scholarship. Against that background, I identify the

${ }^{81}$ R. DwORKIN, HedGeHOGs, supra note _, at 304. 
still-stringent norms that law professors ought to observe in participating in, or declining to join, scholars' briefs. Finally, using the standards applicable to scholars' briefs as a reference point, I discuss the norms of scholarly integrity that ought to apply when law professors are asked to sign joint letters offering purportedly expert legal analysis to nonjudicial decision makers.

\section{A. The Nature of a Brief}

By traditional understanding, a brief is an advocacy document. Briefs aim not merely to inform, but also to persuade. Scholars who join in amicus briefs should therefore be understood as attempting persuasion. Ideally, the law professors who sign such briefs would have conducted as impartial an inquiry as possible before arriving at their conclusions. By identifying themselves as scholars in filing a brief, or as professors whose only interest lies in the optimal development of the law, signatories may implicitly represent that they have done so. Nevertheless, a brief is not a scholarly article, nor does it speak to the same audience that scholarly articles address. In light of these differences, it would seem unduly rigid to insist that the standards of scholarly integrity that apply to articles and books could simply carry over without amendment to scholars' briefs.

Admittedly, it would be possible to resist this conclusion even in the highly general terms in which I have stated it. Scholars' briefs are a species of amicus curiae brief, and one could imagine friends of the court who do not press a particular point of view, but simply aim to call attention to pertinent considerations that might otherwise escape the court's notice. Indeed, in the early decades of American history, selfidentified friends of the court played this role more frequently than they assumed the posture of advocates. $^{82}$ Although it is possible to imagine scholars' briefs reverting to the older understanding, I see no reason to restrict law professors to so constrained a role. Law professors rightly want to influence the development of the law. If law professors with general expertise in a field think that they have identified the best substantive resolution of an issue, they should feel free to say so, and-within limits yet to be identified - to make arguments designed to persuade a court to their point of view.

A second relevant feature of briefs is that they must conform to stringent page or word limits. ${ }^{83}$ Rarely if ever will law professors submitting an amicus curiae brief have the space to say all that they might wish to include if presenting their views in a scholarly book or article. Those joining a scholars' brief should therefore be able to trust courts and most other readers to understand that length limitations will necessitate some-as yet still unidentified-adjustment in the scholarly standards that journal articles and books should meet.

Finally, briefs can be, and often are, submitted on behalf of multiple parties or amici curiae. In order for groups to make collective statements, members must sometimes accommodate the views and preferences of others. Accordingly, it should be

\footnotetext{
${ }^{82}$ See Banner, supra note _..

${ }^{83}$ In the Supreme Court, for example, amici curiae briefs may not exceed 9,000 words. See Sup. Ct. Rule 33.
} 
widely understood that joint briefs do not necessarily reflect every nuance in the views of all or even any of their multiple signatories. It is possible to make sincere affirmations about what the law is or ought to be without believing that those affirmations are as perspicuous, deep, or far-reaching as the subject matter would permit. ${ }^{84}$ The readers of a joint brief, including a joint scholars' brief, should therefore understand that the individual signatories might have framed their arguments, conclusions, and characterizations of authorities at least slightly differently if speaking for themselves alone. As an ethical matter, however, I believe that law professors should maintain a critical and self-critical wariness of pressure and psychological dispositions to accommodate too much in order to be able to go along. Law professors recurrently defend the institution of tenure as a crucial safeguard of the independent thinking that we familiarly say — our job requires. ${ }^{85}$ Beyond a limit, accommodation in order to join the collective statements in a scholars' brief fits uneasily with the ideal of law professors as rigorous independent thinkers.

\section{B. Applying and Adjusting Scholarly Norms}

In considering how the three standards that I identified above as binding on law professors when authoring scholarly books or articles should be altered or relaxed for scholars' briefs, I shall start with the third, which requires confrontation of difficulties in scholarly arguments. This is the scholarly norm that most clearly requires adjustment. Appropriate alterations in other scholarly norms are much smaller.

\section{Confrontation of Difficulties in Arguments}

Given length limitations on amicus briefs, no reasonable reader could expect scholars who must comply with such limitations to address all of the concerns and counterarguments that they would wish to discuss if not so constrained. An analogy supports this conclusion. The page-limited scholars who participate in amicus briefs occupy a role partly similar to that played by law professors who serve as expert witnesses. Although expert witnesses must tell the truth as they see it, the legal rules that define the form in which they present their conclusions also mediate their obligations to confront potential objections to their arguments. A witness can only answer the questions that lawyers ask. A signatory to a brief is not quite so tightly constrained, but is entitled to prefer affirmative arguments to defensive qualifications in the page-limited role in which scholars who act as friends of the court cast themselves. ${ }^{86}$

\footnotetext{
${ }^{84}$ See generally Cass R. Sunstein, Incompletely Theorized Agreements, 108 HARV. L. REV. 1733 (1995) (exploring the phenomenon of agreement on some matters or characterizations in the absence of deeper or further reaching agreement). There is a partial analogy, though only a partially analogy, to judges multimember courts who sometimes compromise their views in order to make it possible for there to an "opinion of the court." There are more pressing institutional or role-based reasons for judges to agree to majority opinions of a court, and the legal clarity that such opinions provide, than for law professors to compromise their views in order to participate in a collective statements.

${ }^{85}$ See AAUP, Statement of Principles on Academic Freedom and Tenure, supra note _..

86 There may be more grounds for worry on this score when amicus briefs present purportedly factual information at too late a stage in litigation for the opposing party "to digest the information, investigate its
} 


\section{Individual, Research-Based Responsibility for Claims Asserted}

There should be less adjustment or relaxation in the standard that normally requires law professors to take personal responsibility for having done the research and performed the analysis on which their stated positions depend. My argument in support of this conclusion is embarrassingly brief and direct: Law professors cannot honestly claim to speak as disinterested legal experts if they make assertions that lack significant foundations in personally conducted research and resulting knowledge. Accordingly, law professors should not join scholars' briefs unless they have a basis in personal knowledge for affirming that all of the briefs' principal assertions of plain fact are true (or are appropriately assumed to be so for purposes of legal argument) and that all of the briefs' principal interpretive claims reflect their sincere views.

Several qualifications are in order here. In saying that a scholar should have a significant basis in personal knowledge for affirming all claims of plain truth, I do not suggest that law professors should not sign scholars' briefs unless they can personally remember every word quoted from every authority and the exact pages on which quotations appeared. Even in a scholarly article or book, a law professor permissibly trusts research assistants to confirm or nail down many details. Similarly, if a law professor has general familiarity with the main authorities cited in a scholars' brief, the professor should be able to trust the work of the brief's author in reporting the more minute details. But only if the representations are consistent with a law professor's personal recollections of the principal authorities on which a brief relies, and if the professor has reason to trust the competence and good faith of the brief's author(s), should a law professor sign in the self-asserted capacity of a scholar (or that of a professor advising the court based on scholarly expertise). A professor signing an amicus brief should similarly accept personal responsibility for having thought through and endorsed the brief's central interpretive and normative claims.

An obvious question to be confronted here arises from an analogy to co-authored scholarship. If a law professor can trust her co-authors to be accurate and analytically rigorous, why can she not similarly trust the author of a scholars' brief, especially if it is written by a distinguished scholar whom she knows to be a person of integrity? To give a concrete example, this question arose for me in connection with the scholars' brief in the complex case about federal jurisdiction that I described in Part I. ${ }^{87}$ The author was Michael Dorf, a scholar whom I hold in extremely high esteem and a person I believe to be of unimpeachable integrity. If the occasion ever arose, I would have no qualms about embracing Dorf as a co-author.

In the case of the scholars' brief that he had drafted, however, it seems pertinent that my instinctive sympathy for the asserted position-and thus my impulse to want to sign-had ideologically based foundations. In my view, when ideological interests or

reliability, and, if necessary, file a response or identify (and persuade) an amicus curiae to file a response on their behalf.” Simard, supra note _, at 706.

${ }^{87}$ See supra note _ and accompanying text. 
political values provide a significant motivation for a law professor to participate in a scholars' brief, she has, if anything, an enhanced obligation to ensure that the views that she espouses are sustainable when tested against the requirements of "integrity," including "fit" or coherence with pertinent legal authorities. ${ }^{88}$ As I said earlier, reflection persuades me that law professors who do not share personal responsibility for all aspects of a co-authored scholarly product (such as a casebook) should, insofar as possible, disclose who bears responsibility for what. In principle, signatories to scholars' briefs could take a similar approach, disclaiming personal responsibility for that of which they lack significant personal knowledge. For example, I might have offered to join Professor Dorf's amicus brief, subject to the inclusion of a disclaimer concerning the limits of my actual knowledge of the authorities on which the brief relied. The practical difficulty, of course, is that too much too candid disclosure of this kind would defeat the very purpose that scholars' briefs seek to achieve, which is to signal that the signatories have arrived at their conclusions based on disinterested legal expertise. Nevertheless, for professors to join some parts of briefs while disclaiming responsibility for others would seem to me to be morally and ethically unexceptionable.

\section{Trustworthiness in Asserting Arguments}

The last remaining scholarly norm on my list involved an obligation of sincerity and trustworthiness in asserting reasons and arguments for conclusions. As framed by requests to sign scholars' briefs, the challenge may be to reconcile the scholar's obligation of trustworthiness in argument with the law professor's professionally approved mission as an advocate for legal justice or law reform. I would propose this test: Before signing scholars' briefs, law professors should first ask themselves how they would respond, in their roles as scholars and teachers, if the court to which the brief is addressed simply adopted the brief's reasoning and language as its own. If a professor would applaud the court for doing so, she should have no compunctions about joining the brief. At the other end of the spectrum, if the professor would criticize the court for relying on misleading characterizations of relevant authorities, purporting to distinguish precedents on untenable bases, or materially oversimplifying relevant history, then she normally ought to withhold her name.

The example of the scholars' brief in support of a federal statute mandating the purchase of health insurance, to which I referred in Part I, may help me elaborate, and perhaps partially qualify, this position. In my judgment, the brief that I was asked to sign fell short of appropriately applicable standards by reciting only historical evidence that would tend to support the constitutionality of the challenged legislation as if that were the only relevant historical evidence. But I also believe that it normally is proper for law professors acting as friends of the court to provide any arguments or information that judges might think relevant or even dispositive, regardless of the significance that the amici themselves attach to it, as long as the amici present the information in trustworthy, non-misleading form. The scholars' brief on the constitutionality of the Patient Protection and Affordable Care Act would thus have satisfied my standards of trustworthiness if,

${ }^{88}$ See supra note _ and accompanying text. 
in addition to piling up evidence tending to indicate a very broad original understanding of the scope of the commerce power-in the expectation that a court would find such information relevant-it had also very briefly said something such as this:

To be sure, there is other evidence bearing on the original understanding, including some suggesting that many members of the Founding generation drew one or more clear lines-such as a line between commerce and manufacturing-that sharply delimited Congress's power. ${ }^{89}$ In truth, there was probably no consensus among the Constitution's framers and ratifiers concerning the precise scope and limits of the Commerce Clause or of how to reconcile competing assumptions that Article I would give Congress power to deal with all problems of genuinely national scope and that it would reserve some domains of regulatory authority exclusively to the states. ${ }^{90}$ Certainly many who either numbered among or closely followed the Founding generation-including Chief Justice John Marshall in Gibbons v. Ogden ${ }^{91}$-understood the Commerce Clause as expansive in scope. ${ }^{92}$ In any event, if it were ever plausible to hold that the Commerce Clause would best be understood to deny Congress the authority to address any significant subset of pressing economic problems that the states are separately incompetent to meet, post-Founding history and precedent make that conclusion no longer tenable. ${ }^{93}$

If a court incorporated language of this kind into its opinion, as part of a broader discussion, its analysis would satisfy applicable ideals of judicial integrity, just as a scholars' brief that included such language would uphold defensible scholarly standards of sincerity and trustworthiness. ${ }^{94}$

The harder cases under my proposed test involve situations in which a professor would approve a court's adoption of a brief's analysis if, but only if, she accepted what she regards as a mistaken premise or regrettable constraint. Imagine, for example, that a professor believes that the truly best legal arguments would show the death penalty to be unconstitutional in all cases, but also recognizes that there is no realistic chance of persuading a court to adopt that view in the case before it. Lower courts are bound by Supreme Court precedents, and a majority of the current Justices appear unshakably

\footnotetext{
89 See, e.g., Randy E. Barnett, The Original Meaning of the Commerce Clause, 68 CHI. L. REV. 101 (2001).

90 See, e.g., U.S. CONST., AMENDMENT X.

9122 U.S. 1 (1824).

92 See id. at 189-98 (expansively defining both "commerce”-as "a general term" that should not be restricted "to one of its significations"-and "regulation").

${ }^{93}$ I refer here to experience in the Lochner, New Deal, and post-New Deal eras that the brief immediately proceeded to discuss very commendably.

${ }^{94}$ In my view, a scholars' brief that only recited historical evidence supporting a broad interpretation of the Commerce Clause, but purported to claim only that, for example, such an interpretation "finds substantial support in the original understanding," would fall short—-though perhaps only barely so-under what I have characterized as the obligations of trustworthiness and confrontation. Although not false, the proffered formulation would be slightly misleading in its failure to acknowledge specific historical evidence that would support rival characterizations of the original understanding.
} 
committed to the view that the death penalty is not per se unconstitutional. Can the professor write or sign a scholars' brief that argues that a particular defendant has a right not to be executed even under precedents that she believes ought not be accepted and that, in her capacity as teacher or scholar, she would criticize the Supreme Court for failing to overturn? Or can a law professor who is a constitutional originalist — and would criticize the Supreme Court for failing to decide a case strictly on originalist grounds-participate in a brief that makes arguments that depend for their validity on non-originalist assumptions?

In cases of this kind, I believe that the standards of trustworthiness applicable to scholars' briefs call for candor. As I have said, law professors acting as amici should be able to call attention to arguments that they expect judges to find relevant, even when the judges' jurisprudential assumptions are ones that the professors do not share. But if the arguments in a scholars' brief depend on premises that the professors who sign it would not embrace in their capacity as teachers or scholars, other than for purposes of argument, then the norm of trustworthiness requires those who participate in the brief to make clear the terms on which they do so. That norm also requires scholars' briefs to advance only such arguments as the signatories sincerely believe to be good ones given the assumptions that they have granted.

\section{Collective Expressions of Purportedly Expert Opinion to Non-Judicial Decision Makers}

During the imbroglio surrounding the impeachment of President Bill Clinton, several hundred law professors - some with no special expertise in constitutional lawsigned a joint letter expressing their judgment that Clinton's alleged misdeeds did not rise to the level of "high crimes and misdemeanors" in the constitutional sense. ${ }^{95}$ Other professors have signed similar letters expressing collective opinions about other issues on other occasions. In my view, the standards of scholarly integrity applicable to such letters closely approximate those that govern scholars' briefs. I shall therefore address those standards in the same order as above.

Where there are good reasons for brevity, the norm that calls for scholarly books and articles fairly to confront non-obvious opposing arguments does not apply with undiluted stringency to joint statements of professional judgment or opinion. Professors should be as entitled as anyone else to assert their conclusions in relatively conclusory form without needing to rehearse all of the relevant, underlying considerations. Frequently, however, there will be powerful tactical reasons to address competing claims that have already entered or are likely to enter public debate.

Although I see no reason to think that a law professor's obligation to take personal responsibility for claims asserted is any different for joint letters than for amicus briefs, the same norm may generate different problems of application in the two cases. Amicus briefs typically make quite specific claims about the content and applicability of identified legal authorities, such as statutes and judicial precedents. By contrast,

\footnotetext{
${ }^{95}$ See supra note
} 
statements of collective opinion in letters to non-judicial decision-makers frequently assert their conclusions without providing any substantial supporting argument. In such cases, the pertinent issue involves a law professor's capacity to present an opinion as reflecting expert knowledge of materials that a collective statement does not specifically discuss. Professor Ward Farnsworth has suggested a number of heuristics for gauging expertise, ${ }^{96}$ one of which seems especially apt. A professor considering whether to join a collective statement should ask herself if she would feel competent to present and defend the collective statement at a faculty workshop. ${ }^{97}$ If not, she should presumptively conclude that she cannot, with integrity, take personal responsibility for the accuracy of the purportedly expert opinion that a letter expresses.

With regard to trustworthiness, a professor should join a collective statement only if she sincerely believes it to be correct and not misleading. She should assure herself that she would not wish to recant the legal judgments that the statement expresses in a future case with different political or partisan implications.

\section{Second Thoughts?}

If my recommendations achieved universal adherence, there would probably be substantially fewer scholars' briefs than there are today, or at least many fewer law professors would sign such briefs. But of course not every law professor will apply the standards that I have advocated. In going forward, I therefore make two assumptions for the sake of argument. First, if morally scrupulous or enlightened law professors began immediately to act on my analysis, they would enjoy less influence on the development of the law than some of them now exert. Second, and correspondingly, morally or ethically less scrupulous law professors-who would continue to join scholars' briefs whenever those briefs argue for a result that they have an ideological disposition to favor-would achieve greater impact. ${ }^{98}$ Given these assumptions, should morally and ethically scrupulous law professors reconsider my prescriptions? Should or must they cede practical influence to the less morally and ethically enlightened?

\section{A. Is It Too Late?}

If we assume that many law professors regularly sign scholars' briefs based more on ideology than on expert knowledge and insight, and that many will continue to do so, it might seem appropriate to reconsider the question whether role-morality might justify them in doing so. If nearly everyone regarded the signing of a scholars' brief as little

\footnotetext{
${ }^{96}$ See Farnsworth, supra note _, at 41-49. Professor Farnsworth initially asserts that "when academics offer opinions in their professional capacities, they should use the same care and have the same expertise called for in their published work," but then offers a number of heuristics unrelated to the publication of scholarship to determine whether this standard is satisfied. See id.

${ }^{97}$ See id. at 45.

${ }^{98}$ Although I assume this to be the case for sake of argument, it is of course possible that judges and Justices would learn over time which law professors are more scrupulous and which are less so, and that the more scrupulous professors would enjoy enhanced credibility in those cases in which their standards for participation were actually met. See, e.g., Lynch, supra note _, at 53 (noting that Supreme Court law clerks report a propensity to value some law professors' briefs more highly than others').
} 
more than an expression of ideological preference, then perhaps participation on that basis would mislead no one and defeat no one's reasonable expectations. There would be no harm to others, and thus, arguably, no wrong.

But this position reflects twin mistakes. To begin with, although there may be growing cynicism about scholars' briefs pretensions to disinterested expertise, the view that no one expects such briefs to satisfy higher, role-based standards of integrity than lawyers' briefs on behalf of clients seems false. As noted above, some number of judges, Justices, and law clerks still regard scholars' briefs as being, as a class, distinctively valuable. ${ }^{99}$ Current and emerging practice may have devalued the currency of scholarly expertise in which all law professors trade, but assertions of scholarly authority do not yet appear to be worthless.

Moreover, even if there were a now-recognized social role of professor-as-signerof-scholars'-briefs, and even if those occupying that role were not generally expected to meet obligations of scholarly integrity, I do not believe that such a role could be justified, any more than the role of a Mafioso is justified by the social expectations surrounding it. If not, then expectations that law professors who join scholars' briefs will not hold the briefs to reasonable standards of scholarly integrity could not excuse occupants of that role from the ordinary, non-role-based moral standards that require people to be truthful and not misleading in their dealings with others. Nothing inherent in the idea of an adversary system requires authorizing law professors to claim to speak with scholarly expertise while making assertions that could not satisfy even reasonably adjusted scholarly norms.

\section{B. The Significance (or Insignificance) of Consequences}

To say that law professors contemplating participation in scholars' briefs are subject to scholarly norms is not necessarily to say that those professors should comply with those norms in every case. In considering what law professors who are asked to participate in scholars' briefs ultimately ought to do, it may seem tempting to compare their situation with that of officials and others in public roles who have the capacity to affect important public policies. As noted earlier, I believe that those with broad responsibilities and capacities to protect the interests of others may sometimes have a moral license or even an obligation to deviate from the deontological norms that predominate in private life and to follow a consequentialist ethic. Professor Nagel maintains that those in public roles should sometimes be "ruthless." ${ }^{100}$ Michael Walzer suggests that people who can achieve sufficiently important results only if they breach moral norms should acquire morally "dirty hands." 101 If these comparisons are apt, law professors who compromise their acknowledged obligations of responsibility, trustworthiness, or confrontation, but do so in order to promote good consequences, might claim adequate justification for doing so, all things considered.

\footnotetext{
${ }^{99}$ See supra notes _____ and accompanying text.

100 See Nagel, Ruthlessness, supra note

${ }^{101}$ See Michael Walzer, The Problem of Dirty Hands, 2 PHIL. \& PuB. AfF. 160 (1973).
} 
Although arguments to this effect might not be frivolous in all cases, it is hard to imagine contexts in which they would not ring hollow. However flattering it might be to be told otherwise, the likelihood that any particular law professor's agreement to join a scholars' brief will actually influence the outcome of a case seems small under nearly all circumstances. Someone else will have prepared a brief already. That brief will most likely attract other signatories. There is no apparent reason to assume, ex ante, that the law professors who too readily join scholars' briefs will tend systematically to take the "wrong" side on the merits.

There are, moreover, two relevant risks. First, a law professor who deviates from the standards of integrity that appropriately apply to scholars' briefs risks further degrading the credibility that the general class of scholars' briefs possesses. This is an important negative externality. Individual law professors ought to hesitate long before undermining the credibility of other law professors to speak sincerely as disinterested scholars.

Second, there is a related risk that deviation from appropriate standards of scholarly integrity will foster the impression that law professors as a class tend to lack scholarly integrity in all contexts. To the extent that this impression exists or takes hold, the result may include the dismissal or discounting not just of scholars' briefs, but also of law professors' books and journal articles. This would be an even more disturbing negative externality of promiscuous participation in scholars' briefs.

\section{Responsibility Revisited}

A further consideration fortifies the conclusions that I have pressed, but also brings new questions of its own. Insofar as the obstacle to participating in an amicus brief involves the law professor's obligation of personal responsibility, a law professor always has the option of putting aside other projects and reading the sources on which a scholars' brief relies. In the case of the brief on federal jurisdiction that I declined to join, I could have pulled out the cases and-as I fully expect-confirmed that I concurred in Professor Dorf's characterizations and in the conclusions that they supported. And if a draft scholars' brief that others have proffered for signature does not satisfy applicable standards of trustworthiness or confrontation, then I or any other law professor who regards a case as urgently important could draft and file her own amicus brief. During the Supreme Court's 2010 Term, at least five law professors filed amicus briefs on behalf of themselves alone. ${ }^{102}$

\footnotetext{
102 They were Professors Mark A. Geistfeld, in Bruesewitz v. Wyeth, 131 S. Ct. 1068 (2011), see 2010 U.S. S. Ct. Briefs LEXIS 514; Richard Friedman, in Bullcoming v. New Mexico, 131 S. Ct. 2705 (2011), see 2010 U.S. S. Ct. Briefs LEXIS 2339; Kristin E. Hickman, in Mayo Foundation v. U.S., 131 S. Ct. 704 (2011), see 2010 U.S. S. Ct. Briefs LEXIS 1925; Carlton M. Smith, also in Mayo Foundation v. United States, see 2010 U.S. S. Ct. Briefs LEXIS 1260; and Gregory N. Sisk, in United States v. Tohono O’odham Nation, 131 S.Ct. 1723 (2011), see 2010 U.S. S. Ct. Briefs LEXIS 1065. Professor Ned A. Waxman, a professor at the College of William and Mary's Maxwell School of business, also filed a solo amicus curiae brief, in Microsoft v. i4i, 131 S. Ct. (2011), see 2011 U.S. S. Ct. Briefs LEXIS 135.
} 
If I am right in insisting on the pertinence of these alternatives, a question obviously arises about whether and when law professors who are asked to join amicus briefs supporting conclusions with which they would expect to agree, but who lack personal familiarity with some of the authorities relied on, should feel obliged to take up the burden of acquiring the requisite knowledge. This may be a difficult question in some cases. Because the role of law professor includes a capacity to achieve some consequences that others could not achieve, it may attract special obligations. It would often be wrong for a doctor not to suspend other projects to stop someone from dying on the street. Most of the time, however, the situation of a law professor asked to sign a scholars' brief will exhibit only a remote similarity to that of a doctor who is uniquely well situated to render urgent care. Among other things, I am assuming for the moment that other law professors will have begun trying to help already.

It would be a mistake, however, to dismiss too cavalierly the thought that law professors, or at least some law professors, might have moral or ethical obligations to work on amicus briefs from time to time. As I have said, there are many ways to live an ethically admirable life as a law professor. But if we think that our participation in amicus briefs might produce good results, we may have duties to do our fair share in promoting those good consequences that law professors are singularly competent to bring about. ${ }^{103}$ Just as wealthy corporate lawyers may have duties to do at least some unpaid work pro bono publico, some law professors might well conclude that they fail to do their fair share unless they lend their talents to the production of amicus briefs in important cases from time to time. If some law professors recurrently work on such briefs, they deserve admiration for their efforts (as long as they comply with other applicable moral and ethical norms).

Nevertheless, I believe that law professors are ordinarily entitled to pursue their own professional projects, especially those of a scholarly nature, rather than being subject to conscription to investigate the sustainability of the claims of scholars' briefs that others ask them to join. ${ }^{104}$ If there are many ways to lead an ethically attractive life as a law

During the Supreme Court's 2009 Term, the majority opinion in Skilling v. United States, 130 S. Ct. 2896 (2010), cited, quoted from, and adopted the position urged by the solo amicus brief of Northwestern Law School Professor Albert Alschuler. See id. at 2933.

103 See AALS, Statement of Good Practices by Law Professors, Sec. 5 ("Responsibilities to the Bar and General Public"), supra note _ ("One of the traditional obligations of members of the bar is to engage in uncompensated public service or pro bono legal activities. As role models for students and as members of the legal profession, law professors share this responsibility.”). Such duties would be analogous but not identical to those falling under what Liam Murphy has called “a 'collective principle of benevolence,' according to which people must sustain only that amount of sacrifice they would be required to sustain if everyone were doing their part.” Liam Murphy, Beneficence, Law, and Liberty: The Case of Required Rescue, 89 GEO. L.J. 605, 652 (2001).

${ }^{104}$ See AALS, Statement of Good Practices by Law Professors, Sec. 5 ("Responsibilities to the Bar and General Public”), supra note _ (observing that law professors’ public service responsibilities “can be met in a variety of ways, including direct client contact through legal aid or public defender offices (whether or not through the law school), participating in the legal work of public interest organizations, lecturing in continuing legal education programs, educating public school pupils or other groups concerning the legal 
professor, we are ordinarily entitled to decide for ourselves how to do so. Given their distinctive talents, some law professors might rightly regard frequent devotion of energy to amicus briefs as being both ethically attractive and personally rewarding. Others might just as reasonably think that they both satisfy their duties of benevolence and live better as law professors by contributing to the public good in other ways.

\section{Conclusion}

With respect to questions of professional identity, many of today's law professors want to be valued as scholars on a par with professors on faculties of arts and sciences who devote their careers to the sometimes lonely search for truth or honest insight. Yet many also aspire to achieve an immediate influence on public events in ways that few members of faculties of arts and sciences could dream of. In seeking to realize the latter ambition, we may face temptations to tailor our arguments to our audiences, to overstate the strength of the support for our conclusions, and to omit to say what would reduce our impact.

The vocation of a law professor is not exclusively that of a scholar. We can, and should, play multiple roles. In doing so, however, we should remember that when we attempt to influence public matters, we almost inevitably seek to trade on the credibility that we-and our predecessors and colleagues-have earned in the roles of scholar and teacher. Those roles create obligations of responsibility, trustworthiness, and confrontation. If emerging norms in the signing of scholars' briefs betray expectations of scholarly responsibility, trustworthiness, and confrontation that we have sought to promote, or seek to capitalize upon, then we should hold ourselves to higher standards.

My argument for this conclusion has sounded largely in the domain of morals, or of what we owe to each other: When we claim to speak with the authority of scholars, we engender — and indeed aim to engender-expectations of responsibility, trustworthiness, and confrontation. If we fail to meet the reasonable expectations that we create or try to trade upon, we behave wrongly. The wrongs that we do may not be large, but they are wrongs nonetheless

Although this conclusion sounds in a sternly moralistic register, many of the hardest questions about the vocation of a law professor are less moral than ethical, involving the relative worthiness of morally eligible choices. Is it better for a law professor to devote her professional energies to scholarship, law reform projects, consulting activities, paid or pro bono work for individual clients, public education through publications in or appearances on the mass media, participation in amicus briefs in high-stakes cases, or any of myriad other activities? Questions such as this have no single, determinate, generalizable answer. There are many ways to live well as a law professor. A thousand flowers ought to bloom, as they do today and undoubtedly will in the future.

system, advising local, state and national government officials on legal issues, engaging in legislative drafting, or other law reform activities.”). 
But there are limits. Amid the burgeoning gardens of law professors' professional activities, I have argued for careful distinctions among the sub-roles that law professors play and for attention to the sometimes varied demands of responsibility, trustworthiness, and confrontation that may apply within those various sub-roles. When law professors purport to speak as scholars or disinterested legal experts, those demands grow more stringent than is often recognized today. 